\title{
Fermentation of Biodegradable Organic Waste by the Family Thermotogaceae
}

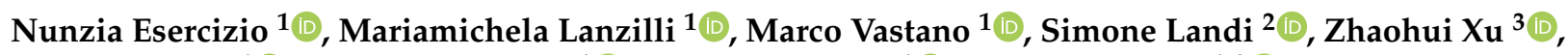

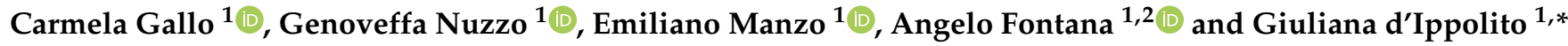 \\ 1 Institute of Biomolecular Chemistry, National Research Council of Italy, Via Campi Flegrei 34, \\ 80078 Pozzuoli, Italy; n.esercizio@icb.cnr.it (N.E.); m.lanzilli@icb.cnr.it (M.L.); \\ marco.vastano@gmail.com (M.V.); carmen.gallo@icb.cnr.it (C.G.); nuzzo.genoveffa@icb.cnr.it (G.N.); \\ emanzo@icb.cnr.it (E.M.); afontana@icb.cnr.it (A.F.) \\ 2 Department of Biology, University of Naples "Federico II", Via Cinthia, I-80126 Napoli, Italy; \\ simone.landi@unina.it \\ 3 Department of Biological Sciences, Bowling Green State University, Bowling Green, OH 43403, USA; \\ zxu@bgsu.edu \\ * Correspondence: gdippolito@icb.cnr.it
}

\section{check for} updates

Citation: Esercizio, N.; Lanzilli, M.; Vastano, M.; Landi, S.; Xu, Z.; Gallo, C.; Nuzzo, G.; Manzo, E.; Fontana, A.; d'Ippolito, G. Fermentation of Biodegradable Organic Waste by the Family Thermotogaceae. Resources 2021, 10, 34. https://doi.org/10.3390/ resources10040034

Academic Editors: Ezio Riggi, Raffaella Maria Balestrini and Edoardo Marco Napoli

Received: 23 February 2021

Accepted: 9 April 2021

Published: 13 April 2021

Publisher's Note: MDPI stays neutral with regard to jurisdictional claims in published maps and institutional affiliations.

Copyright: (c) 2021 by the authors. Licensee MDPI, Basel, Switzerland. This article is an open access article distributed under the terms and conditions of the Creative Commons Attribution (CC BY) license (https:/ / creativecommons.org/licenses/by/ $4.0 /)$.

\begin{abstract}
The abundance of organic waste generated from agro-industrial processes throughout the world has become an environmental concern that requires immediate action in order to make the global economy sustainable and circular. Great attention has been paid to convert such nutrientrich organic waste into useful materials for sustainable agricultural practices. Instead of being an environmental hazard, biodegradable organic waste represents a promising resource for the production of high value-added products such as bioenergy, biofertilizers, and biopolymers. The ability of some hyperthermophilic bacteria, e.g., the genera Thermotoga and Pseudothermotoga, to anaerobically ferment waste with the concomitant formation of bioproducts has generated great interest in the waste management sector. These biotechnologically significant bacteria possess a complementary set of thermostable enzymes to degrade complex sugars, with high production rates of biohydrogen gas and organic molecules such as acetate and lactate. Their high growth temperatures allow not only lower contamination risks but also improve substrate solubilization. This review highlights the promises and challenges related to using Thermotoga and Pseudothermotoga spp. as sustainable systems to convert a wide range of biodegradable organic waste into high value-added products.
\end{abstract}

Keywords: Thermotoga; Pseudothermotoga; thermophilic bacteria; fermentation; hydrogen; lactic acid; waste valorization; added-value products

\section{Introduction}

Biodegradable organic waste from industrial processes provide versatile carbon-rich feedstocks that can be efficiently converted into high-value products and biofuels [1-3]. As described in the 2018 EU Bioeconomy Strategy report [4], the economic value of biodegradable waste is starting to be recognized by agricultural, forestry, chemical, and energy sectors. With the development of the bioeconomy, the demand for these secondary products is likely to increase, changing the economic conditions of production. More than 3300 megatonnes of residual biomass are estimated to be generated annually from barley, maize, rice, soybean, sugar cane, and wheat. In Europe only, 900 megatonnes of wastepaper, food, and plant materials are generated each year. In the fisheries sector, about 40 megatonnes of fish may be discarded each year during European commercial fishing; in the forestry sector, woody biomass residues have been estimated to be 5100 megatonnes per year globally [4].

From the perspective of constructing a circular economy based on biowaste, it is important to support the development of industrial symbiosis for feed materials, i.e., one 
industry's waste becomes the starting material for another. One example is the treatment of waste and residues for energy production, including the production of biogas through anaerobic digestion of biowaste and wastewater [5-9] as well as the integrated production of chemical products and bioenergy in biorefineries $[10,11]$. The food processing industry is exploring the potential of recovering the energy contained in food residues on site [12-14]. A typical fermentation process consists of the controlled digestion of biodegradable materials under anaerobic conditions in closed reactors, at temperatures suitable for mesophilic or thermophilic bacteria. Fermentation products include (1) digestated solids that can be used as a soil conditioner; (2) biogas that can be consumed directly or refined for higher levels of demands, such as fuels for vehicles.

In this framework, special attention has been paid to fermentation processes in which biowaste is treated for generating hydrogen gas $[15,16]$. Hydrogen represents a promising bioenergy fuel since it is clean, renewable, abundant, and cheap; it produces only water as the end-product when used as a fuel, without any pollutants [17-19]. Dark fermentation operated by anaerobic thermophilic bacteria is an attractive way to produce biohydrogen because of the high biogas evolution yields and the versatile feedstocks [17,18,20-24]. Among extreme thermophilic bacteria, members of the order Thermotogales have proven to be promising candidates due to high $\mathrm{H}_{2}$ yields that are close to theoretical values and the ability of some members to recycle produced $\mathrm{CO}_{2}$ into lactic acid synthesis [25-35]. These bacteria are capable of fermenting not only simple and pure sugars but also complex carbon sources with various production rates [36-41].

This review focuses on the potential of the members of the order Themotogales to ferment biodegradable organic waste. Feedstock pretreatments and their effects on cultural parameters are also discussed [24,42-44]. With the development of molecular and biochemical tools applicable to extremophilic bacteria, it has been possible to demonstrate the involvement of specific enzymes and putative pathways in the uptake and degradation processes [45-47], offering new routes in the evaluation of the application of these biological systems.

The examined substrates discussed here are divided into four groups, based on their main constituents and relative origins: food waste, lignocellulosic waste, glycerol, and microalgal biomass. Their main characteristics, compositions, utility, and fermentation processes involving Thermotogaceae family members are discussed in subheadings, and the best results are summarized in tables. It provides a concise and precise description of the experimental results, their interpretation as well as the conclusions drawn from the studies.

\section{Thermotogaceae Family: Features and Roles in Sugar Fermentation}

\subsection{General Characteristics}

The phylum Thermotogae represents a critical node in the phylogenetic tree of bacteria. Bhandari and Gupta's classification was taken as a model because it was based on genomic data from several Thermotogae species, and the molecular markers were identified to estimate the relationship within the phylum [48]. Recently, with the significant advances in modern taxonomy practices, Belahbib et al. [49] have proposed some changes to Bhandari and Gupta's classification system. Nowadays, the phylum Thermotogae, comprising of mesophilic, thermophilic and hyperthermophilic bacteria, has more than 52 species belonging to four orders: Thermotogales, Kosmotogales, Petrotogales and Mesoacidotogales [50]. The order of Thermotogales includes two families, Thermotogaceae and Fervidobacteriaceae, and their species are distinguished by the shared presence of conserved sequences [48-50]. The family Thermotogaceae contains two genera, Thermotoga and Pseudothermotoga, which are anaerobic, rod-shaped bacteria, surrounded by a sheath-like structure called "toga", resulting in large periplasmic spaces at the poles of each rod $[28,48]$. The genus Thermotoga retains the species T. maritima, T. neapolitana, T. petrophila, T. naphthophila, Thermotoga sp. EMP, Thermotoga sp. A7A, and Thermotoga sp. RQ2, while P. lettingae, P. thermarum, P. elfii, P. subterranea, and P. hypogea belong to the new genus Pseudothermotoga $[28,48,49]$. Members of the Thermotogaceae family have been isolated from geothermal environments across the 
globe, including oil reservoirs, submarine hot springs, and continental solfataric springs, with their optimal growth temperature in the range of $77-80^{\circ} \mathrm{C}$ [28]. They can reduce elemental sulfur and use hexoses, pentoses, disaccharides, glucans, xylans, glucomannan, galactomannan, pectin, chitin, and amorphous cellulose as main substrates during fermentation [28,48]. Thermotoga species generate $\mathrm{H}_{2}$ close to the Thauer limit for anaerobic fermentation (i.e., $4 \mathrm{~mol} \mathrm{H}_{2} / \mathrm{mol}$ glucose), $\mathrm{CO}_{2}$, acetate, and other minor products such as lactic acid, ethanol, and alanine [28,51]. According to the classical model of fermentation referred to as dark fermentation (DF), Thermotoga spp. harvest energy mainly by glycolysis via the Embden-Meyerhoff-Parnas pathway (EMP), although a simultaneous activation of $15 \%$ of the Entner-Doudoroff pathway (ED) has been described [25,52]. EMP is the most common route for oxidation of glucose (and other hexoses) and to supply energy (ATP), reducing equivalents (NADH), and pyruvate, which undergoes terminal oxidation (acetate) or is used for biosynthesis (e.g., acetyl-CoA) [25,53,54]. Moreover, some members of the Thermotogaceae family possess an unprecedented anaplerotic mechanism, called capnophilic lactic fermentation (CLF), that represents the first example of biological non-autotrophic sequestration of $\mathrm{CO}_{2}$ in hyperthermophilic bacteria, more advantageous than classical dark fermentation regarding the production of hydrogen through degradation of carbon substrates $[32,33,55-57]$. This process is activated during glucose fermentation under $\mathrm{CO}_{2}$ sparging, and it is based on the coupling of acetate and $\mathrm{CO}_{2}$ derived from glycolysis to produce enantiopure L-lactic acid without affecting $\mathrm{H}_{2}$ yields $[32,33,55,56,58-60]$. This mechanism was extensively studied in Thermotoga neapolitana, and only a few members of the Thermotoga and Pseudothermotoga genera operated this $\mathrm{CO}_{2}$ recycling mechanism [34]. Under CLF conditions, the bacteria also shift their glucose utilization through downregulation of EMP, activation of ED and/or OPP pathways, and the upregulation of some bifurcating enzymes that could supply NADH in these metabolic processes [60].

These advantageous properties of Thermotoga spp., i.e., valorization and transformation of biodegradable organic waste with $\mathrm{H}_{2}$ production and, in some cases, the sequestration of $\mathrm{CO}_{2}$ to recover energy and generate value-added products, have positioned these bacteria as promising candidates in the biotechnological field. In addition, many of their enzymes are capable of deconstructing complex biomass into basic components for fermentation [46,61]. Although biohydrogen production from hyperthermophilic bacteria is far from an industrial scale application, these studies provide common knowledge about the potential of the family Thermotogaceae, fueling interest in future exploration.

\subsection{Fermentation of Pure Monosaccharides and Polysaccharides}

Members of the Thermotogaceae family can ferment a wide range of mono- and polysaccharides as carbon and energy sources. In the identification processes of each new Thermotoga species, the authors tested a panel of pure monosaccharides to analyze strain adaptability and discovered potential alternative carbon sources for these organisms [28,36,37,62-69]. In the past a few years, independent work also evaluated the effects of monosaccharides on fermentation end-product yields, mainly in T. maritima and T. neapolitana. Glucose is the preferred substrate, and it produces the greatest amount of hydrogen, with yields higher than $3.5 \mathrm{~mol} / \mathrm{mol}$ glucose [36,38,70-73]. Using other sugars as the sole carbon source, such as arabinose, fructose, mannose, galactose and ribose, resulted in similar hydrogen production rates in both species ( $\mathrm{H}_{2}$ yields around $3 \mathrm{~mol} / \mathrm{mol}$ sugar) $[28,36,58,73-77]$.Variations in sugar concentration seem to remarkably affect the $\mathrm{H}_{2}$ production and substrate utilization in T. neapolitana [72]; in T.maritima, lower $\mathrm{H}_{2}$ yields have been observed (around $1.1 \pm 0.1 \mathrm{~mol} \mathrm{H}_{2} / \mathrm{mol}$ xylose) [77].

Thermotoga spp. can also metabolize pure di- and tri-saccharides, such as sucrose, lactose, maltose and cellobiose, and polysaccharides including starch, glycogen, carboxymethyl cellulose (CMC) and cellulose [28,72,73,77-84]. The ability to hydrolyze and ferment a wide range of polysaccharides represents the basis of the great potential and versatility for biodegradable organic waste valorization by the family Thermotogaceae. 
Cellobiose was tested with T. maritima at the concentration of $12.5 \mathrm{mmol} / \mathrm{L}$, resulting in $100 \mathrm{mmol} / \mathrm{L}$ of hydrogen [77]. At the end of the fermentation, $3.6 \pm 0.2 \mathrm{~mol} \mathrm{H}_{2} / \mathrm{mol} \mathrm{sugar}$ was obtained, even though only $49 \%$ of the cellobiose was consumed (Table 1 ), suggesting that cellobiose is a difficult substrate to hydrolyze and may require a different modulation of enzyme activity. Improvements in hydrolysis of cellulosic materials and in $\mathrm{H}_{2}$ production are possible by cocultivating T. maritima with Caldicellulosiruptor saccharolyticus [77].

Regarding sucrose, studies with T. neapolitana showed that the fermentation process was similar to that using glucose [72,73]. In Ngo et al., sucrose consumption rate, acetic and lactic acid production rates were comparable in batch cultures with and without $\mathrm{pH}$ control. A slight increase in $\mathrm{H}_{2}$ yield was observed in sucrose-based culture (Table 1) [72] The same trend was observed under the CLF condition in sucrose fermentation, producing $2.56 \pm 0.1 \mathrm{~mol}$ of $\mathrm{H}_{2}, 25.12 \pm 1.43 \mathrm{mM}$ of acetate, and $16.95 \pm 1.34 \mathrm{mM}$ of lactic acid per mole of glucose equivalent (Table 1) [73].

Fermentation of laminarin led to $\mathrm{H}_{2}$ yield ( $3.70 \pm 0.17$ mol per mole glucose eq) and acetic acid production $(28.75 \pm 0.81 \mathrm{mM})$ in T. neapolitana sp. capnolactica (T.nea clf) culture, similar to glucose and sucrose fermentation. However, LA level $(7.60 \pm 0.27 \mathrm{mM})$ was two times lower (Table 1) [73].

On CMC, a clear reduction of $\mathrm{H}_{2}$ and organic acid production was observed in T. nea clf because this substrate is poorly metabolized [73,82]. Nguyen et al. described the capability of T. neapolitana and T. maritima to grow on CMC [82]. Only $95.5 \pm 4.8 \mathrm{~mL}$ and $96.4 \pm 4.8 \mathrm{~mL}$ $\mathrm{H}_{2}$ /g glucose eq. were produced by T. maritima and T. neapolitana growing on CMC, while $187.1 \pm 9.4$ and $174.5 \pm 8.7 \mathrm{~mL} \mathrm{H}_{2} / \mathrm{g}$ glucose eq. were produced by the two strains, respectively, when growing on starch. (Table 1) [82].

The same effect was observed in T. neapolitana subsp. capnolactica growing on CMC, with a $\mathrm{H}_{2}$ yield of $2.05 \pm 0.13 \mathrm{~mol} \mathrm{H}_{2}, 3.40 \pm 0.30 \mathrm{mM}$ of $\mathrm{AA}$, and $1.18 \pm 0.05 \mathrm{mM}$ of LA per mol of glucose eq. In contrast to other sugars, only $10 \%$ of CMC was consumed after $72 \mathrm{~h}$ of fermentation, indicating that CMC should probably be pretreated to improve its accessibility to the cells [73]. No growth was observed with P. elfii growing on sucrose and CMC [85].

Several papers reported that T. maritima and T. neapolitana were able to degrade cellulose $[17,22,86]$, which stimulated further research on the topic. Nguyen et al. [82] showed a drastic decrease in $\mathrm{H}_{2}$ yields in both T. neapolitana and T. maritima growing on cellulose, with only $27.8 \pm 1.3 \mathrm{~mL} \mathrm{H}_{2} / \mathrm{g}$ glucose eq. for T. maritima and $30.7 \pm 1.5 \mathrm{~mL} \mathrm{H}_{2} / \mathrm{g}$ glucose eq. for T. neapolitana, suggesting that pretreatment is needed to better ferment this substrate (Table 1) [82]. In Nguyen et al. [81], pure cellulose was pretreated with three different chemical methods, acid $\left(\mathrm{H}_{2} \mathrm{SO}_{4}\right)$, alkali $(\mathrm{NaOH})$, and ionic liquid $([\mathrm{C} 4 \mathrm{mim}] \mathrm{Cl}$, 1-butyl-3-methylimidazolium chloride). Ionic liquid turned out to be the most effective pretreatment agent, with $18 \%$ of cellulose dissolution [81]. $\mathrm{N}_{2}$ sparging leads to an improved $\mathrm{H}_{2}$ production rate in T. neapolitana growing on cellulose, reaching $1280 \pm 58.0 \mathrm{~mL} \mathrm{H}_{2} / \mathrm{L}$ culture and $2.20 \pm 0.10 \mathrm{~mol} \mathrm{H}_{2} / \mathrm{mol}$ glucose eq., compared to $1.22 \pm 0.067 \mathrm{~mol} \mathrm{H}_{2} / \mathrm{mol}$ glucose eq. without sparge; this demonstrates the feasibility of using cellulose and other complex feedstocks in Thermotoga fermentation [81]. 
Table 1. Fermentation of pure polysaccharides by Thermotoga spp.

\begin{tabular}{|c|c|c|c|c|c|c|c|c|c|c|c|}
\hline Substrate & Strain & $\begin{array}{c}\mathrm{T} \\
\left({ }^{\circ} \mathrm{C}\right)\end{array}$ & Start $\mathrm{pH}$ & $\begin{array}{l}\text { Mixing Speed } \\
(\mathrm{rpm})\end{array}$ & $\begin{array}{c}\text { Gas } \\
\text { Sparge }\end{array}$ & $\begin{array}{c}\text { Reactor } \\
\text { Volume } \\
\text { (mL) }\end{array}$ & $\begin{array}{l}\text { Working } \\
\text { Volume } \\
(\mathrm{mL})\end{array}$ & $\begin{array}{l}\text { Substrate } \\
\text { Consumption } \\
(\mathrm{mmol} / \mathrm{L})\end{array}$ & $\begin{array}{c}\mathrm{H}_{2} \text { yield } \\
\text { (mol } \mathrm{H}_{2} / \mathrm{mol} \\
\text { sugar) }\end{array}$ & $\begin{array}{l}\text { Organic acids } \\
\text { Production } \\
(\mathrm{mM})\end{array}$ & Ref. \\
\hline Sucrose & T.nea cf & 80 & 7.5 & 250 & $\mathrm{CO}_{2}$ & 3800 & 500 & $23.30 \pm 0.69$ & $2.56 \pm 0.1$ & $\begin{array}{l}\text { AA } 25.12 \pm 1.43 \\
\text { LA } 16.95 \pm 1.34\end{array}$ & \multirow{3}{*}[73]{} \\
\hline Laminarin & T.nea cf & 80 & 7.5 & 250 & $\mathrm{CO}_{2}$ & 3800 & 500 & $24.73 \pm 0.40$ & $3.70 \pm 0.17$ & $\begin{array}{c}\text { AA } 28.75 \pm 0.81 \\
\text { LA } 7.60 \pm 0.27\end{array}$ & \\
\hline $\mathrm{CMC}$ & T.nea cf & 80 & 7.5 & 250 & $\mathrm{CO}_{2}$ & 3800 & 500 & $2.75 \pm 0.25$ & $2.05 \pm 0.13$ & $\begin{array}{l}\text { AA } 3.40 \pm 0.30 \\
\text { LA } 1.18 \pm 0.05\end{array}$ & \\
\hline \multirow{2}{*}{ Sucrose } & \multirow{2}{*}{ T.nea } & \multirow{2}{*}{75} & $\begin{array}{c}7.5 \\
\mathrm{pH} \text { control } \\
\end{array}$ & \multirow{2}{*}{300} & \multirow{2}{*}{$\mathrm{N}_{2}$} & \multirow{2}{*}{3000} & \multirow{2}{*}{1000} & $14.69 \pm 0.06$ & $4.95 \pm 0.25$ & $\begin{array}{c}\text { AA } 25.66 \\
\text { LA } 1.69\end{array}$ & \multirow{2}{*}[72]{} \\
\hline & & & $\begin{array}{c}7.5 \mathrm{w} / \mathrm{o} \\
\mathrm{pH} \text { control }\end{array}$ & & & & & $13.78 \pm 0.70$ & $3.52 \pm 0.18$ & $\begin{array}{c}\text { AA } 23.97 \\
\text { LA } 2.5\end{array}$ & \\
\hline \multirow{2}{*}{$\begin{array}{l}\text { Cellulose pretreated } \\
\text { with }[\mathrm{C} 4 \mathrm{mim}] \mathrm{Cl}\end{array}$} & \multirow{2}{*}{ T.nea } & \multirow{2}{*}{80} & \multirow{2}{*}{7.5} & \multirow{2}{*}{150} & $\mathrm{~N}_{2}$ & \multirow{2}{*}{120} & \multirow{2}{*}{40} & \multirow{2}{*}{-} & $2.20 \pm 0.1$ & \multirow{2}{*}{-} & \multirow{2}{*}{ [81] } \\
\hline & & & & & $\mathrm{w} / \mathrm{o} \mathrm{N}_{2}$ & & & & $1.22 \pm 0.067$ & & \\
\hline Cellulose & T.nea & 80 & 7.5 & - & $\mathrm{N}_{2}$ & 120 & 50 & $10.18 \pm 0.08$ & $30.7 \pm 1.5^{*}$ & AA 4.09 & \multirow{5}{*}{ [82] } \\
\hline \multirow{2}{*}{ Starch } & T.nea & 80 & 7.5 & \multirow{2}{*}{-} & \multirow{2}{*}{$\mathrm{N}_{2}$} & \multirow{2}{*}{120} & \multirow{2}{*}{50} & $5.51 \pm 0.09$ & $174 \pm 8.7^{*}$ & AA 22.04 & \\
\hline & T.mar & 75 & 6.5 & & & & & $6.01 \pm 0.09$ & $187 \pm 9.4 *$ & AA 24.34 & \\
\hline \multirow{2}{*}{$\mathrm{CMC}$} & T.nea & 80 & 7.5 & \multirow{2}{*}{-} & \multirow{2}{*}{$\mathrm{N}_{2}$} & \multirow{2}{*}{120} & \multirow{2}{*}{50} & $6.80 \pm 0.08$ & $96.4 \pm 4.8^{*}$ & AA 8.97 & \\
\hline & T.mar & 75 & 6.5 & & & & & $6.99 \pm 0.08$ & $95.5 \pm 4.8$ * & AA 9.75 & \\
\hline Cellobiose & T.mar & 70 & 7.2 & 90 & $\mathrm{~N}_{2}$ & 120 & 50 & 6.125 & $3.60 \pm 0.2$ & - & [77] \\
\hline
\end{tabular}

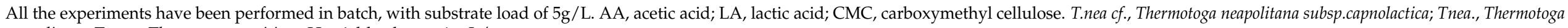
neapolitana; T.mar., Thermotoga maritima. $\mathrm{H}_{2}$ yield column: * $\mathrm{mL} / \mathrm{g}$. 


\section{Biodegradable Organic Waste}

Biodegradable organic waste represents the main end-products from agro-industrial processes and nowadays serve as popular feedstocks for anaerobic fermentation [1-3]. These biomass materials contain carbohydrates, lipids, lignocellulosic compounds and proteins, which provide a balanced supply of carbon, nitrogen, sulfur, minerals, vitamins, and other small molecules [14]. Over the years, organic biomass has acquired an increasingly important role because of their abundance and low costs. Originally considered the "waste" of industrial processes, they represent a new economic opportunity to enhance energy production $[1-3,6,9,10,13]$.

\subsection{Food Waste}

Food waste is generated by the entire food system, from production to processing and to consumption, although there are considerable uncertainties about the estimated quantities related to different stages. Food waste comes from various sources including agro-industrial processes, households, and the hospitality sector. It is generally composed by carbohydrates, protein, lipids and inorganic compounds, in variable proportions depending on the source of the food waste. Their accumulation associated to population growth has become a serious problem [87]. The food processing industries are exploring the potential of recovering the energy contained in food residues on-site, through biogas production or in dedicated combined heat and power plants. Anaerobic digestion is an effective way to manage food waste, with advantages like low costs, less residual waste and production of biohydrogen [10-12,88]. Of the food waste available, only some of it will be discussed in this review based on their applications in Thermotoga fermentation.

\subsubsection{Fruit and Vegetable Waste}

Fruit and vegetable waste (FVW) is the most abundant waste obtained in wholesale markets. These substrates are mainly composed of carbohydrates, cellulose, and hemicellulose, making them good candidates to produce biohydrogen [89-91]. It is already known that these compounds are used to produce biogas and to reduce landfill maintenance costs due to their high organic content and good degradability [5,39,89-91]. Moreover, no special pretreatments are required for these substrates, simply the reduction in size with an electric blender and subsequent filtration and homogenization. This procedure guarantees the absence of extremophilic and/or halotolerant microflora that are able to produce $\mathrm{H}_{2}$, and allows for better sugar solubilization. Saidi at al. studied fruit and vegetable waste fermentation with $T$. maritima, using a simplified medium containing natural seawater as the inorganic compound source [39]. Under this experimental condition, $3.89 \pm 0.05 \mathrm{~mol} \mathrm{H}_{2} / \mathrm{mol}$ hexose, $1.96 \mathrm{~mol} \mathrm{AA} / \mathrm{mol} \mathrm{C} 6$ and $1.2 \pm 0.2 \mathrm{mmol} \mathrm{LA} / \mathrm{L}$ were obtained (Table 2) [39].

Carrot pulp is a vegetable residue obtained in carrot juice production, thus available in large quantities as a by-product. It is composed of a soluble water fraction $(30 \%)$ consisting of sucrose, glucose and fructose, and a considerable amount of insoluble nonstarchy polysaccharides (NSP) (30-40\% of the total dry matter) derived from cell wall hemicellulose and pectin $[75,92]$. Glucose was the most abundant residue in the NSP fraction, while in much lower concentrations were arabinose, galactose, mannose, rhamnose, xylose, and galacturonic acid derived from pectin $[75,92]$. Both the untreated material and the hydrolysate fraction were tested in T. neapolitana fermentation, and the importance of pretreatment was highlighted. After the enzymatic hydrolysis of the insoluble polysaccharide fraction by cellulases, the soluble sugar content in the total liquid hydrolysate increased, for example, $160 \mathrm{~g}$ of dry matter produced $4.0 \mathrm{~g} / \mathrm{L}$ of sucrose, $39.2 \mathrm{~g} / \mathrm{L}$ of glucose and $14.0 \mathrm{~g} / \mathrm{L}$ of fructose. However, $30 \%$ of the initial dry matter remained insoluble [75]. T. neapolitana only fermented the hydrolyzated form, producing $2.4 \mathrm{~mol} \mathrm{H}_{2} / \mathrm{mol} \mathrm{C} 6,1.1 \mathrm{~mol} \mathrm{AA} / \mathrm{mol} \mathrm{C} 6$, and $0.30 \mathrm{~mol} \mathrm{LA} / \mathrm{mol} \mathrm{C6}$ (Table 2). A reduction of sugar consumption rate was observed compared to pure sugar fermentation, maybe due to the insoluble residual fraction that can inhibit fermentation [75]. 
Potato steam peels (PSP) derive from the potato processing industry. This waste is rich in starch, and it is available in large quantities. It is generally used for animal feeding but is now regarded as a potential substrate in biohydrogen production [93]. In fact, a life cycle assessment showed that it is more beneficial to primarily use PSP to produce hydrogen and use protein-rich solids in animal feed, rather than using potato steam peels directly [94]. Mars et al. described $\mathrm{H}_{2}$ production during T. neapolitana fermentation with potato steam peels as the carbon source [95]. Different pretreatment states of PSP were used as organic substrates (untreated PSP, PSP-H1 and PSP-H2). Untreated PSP is composed of 39\% starch, $3.8 \%$ nitrogen, and $8.5 \%$ ash. PSP treated with alpha-amylase and then clarified, referred to as PSP-H1, contains soluble dextrins, $21 \mathrm{mM}$ glucose, $7 \mathrm{mM}$ acetate, and $25 \mathrm{mM}$ lactate. PSP-H1 further hydrolyzed with amyloglucosidase and clarified, referred to as PSP-H2, contained $407 \mathrm{mM}$ glucose, $10 \mathrm{mM}$ acetate, and $33 \mathrm{mM}$ lactate [95]. Untreated PSP led to an $\mathrm{H}_{2}$ yield of $3.8 \mathrm{~mol} \mathrm{H}_{2} / \mathrm{mol}$ glucose units with $1.80 \mathrm{~mol} \mathrm{AA} / \mathrm{mol}$ glucose units and $0.2 \mathrm{~mol}$ LA/mol glucose units by T. neapolitana (Table 2) [95]. This high hydrogen yield based on starch content in PSP could be an overestimation because other unidentified substrates in PSP may have also been consumed. Using PSP-H1 and PSP-H2, a decrease of all product yields was observed (PSP-H1: $2.6 \mathrm{~mol} \mathrm{H} / 2$ mol glucose, $1.20 \mathrm{~mol} \mathrm{AA} / \mathrm{mol}$ glucose. PSP-H2: $3.3 \mathrm{~mol} \mathrm{H}_{2} / \mathrm{mol}$ glucose, $1.50 \mathrm{~mol} \mathrm{AA} / \mathrm{mol}$ glucose) [95]. Therefore, untreated PSP may be a suitable alternative to the use of hydrolysates.

Onion waste (OW) is the result of industrial onion (Allium cepa L.) cultivation, harvesting and processing. Nowadays onions are the second most important horticultural crop worldwide after tomatoes. The increase in onion demand over the years has led to an increase in onion waste production, representing an environmental concern. They are not suitable for fodder because of their aroma, and neither can they serve as an organic fertilizer because of the rapid development of phytopathogenic agents. Onion waste mainly includes undersized, malformed, diseased or damaged bulbs as well as onion skins, outer fleshy scales and roots that are generated during industrial peeling [96]. However, since onions are rich in several groups of plant compounds, such as dietary fibers (DF), fructo-oligosaccharides (FOS) and flavonoids, they have many benefits to human health [96]. An alternative solution could be their biological conversion into bioenergy and high value-added products (food and pharmacological ingredients, biogas, fertilizers, etc.) [41,97-99]. Up to $65 \%$ of the dry weight of onion waste is composed of nonstructural carbohydrates, including fructose $(114 \pm 1.4 \mathrm{mmol} / \mathrm{L})$, glucose $(137.5 \pm 0.9 \mathrm{mmol} / \mathrm{L})$ and sucrose $(21 \pm 0.7 \mathrm{mmol} / \mathrm{L})$ [41]. They also contain sulfur, proteins, minerals, cellulose $(7 \pm 1.4 \mathrm{~g} / \mathrm{L})$, hemicellulose $(3 \pm 1.9 \mathrm{~g} / \mathrm{L})$, and essential oils. $\mathrm{H}_{2}$ production was evaluated in T. maritima using onion waste alone or in combination with other FVW to provide additional nutrients for growth. Substrates were cut with an electric blender into small pieces, filtered and then homogenized [41]. Using a simplified medium containing natural seawater, cysteine- $\mathrm{HCl}$ and $\mathrm{NH}_{4} \mathrm{Cl}$ as inorganic nitrogen source, T. maritima metabolized $60 \%$ of the carbohydrates contained in onion waste to produce $124 \pm 2.5 \mathrm{mmol} \mathrm{H}_{2} / \mathrm{L}$ (yield of $3.76 \pm 0.5 \mathrm{~mol} \mathrm{H}_{2} / \mathrm{mol} \mathrm{C6}$ ), $65 \pm 2.7 \mathrm{mmol} \mathrm{AA} / \mathrm{L}$ (yield of $1.97 \mathrm{~mol} \mathrm{AA} / \mathrm{mol} \mathrm{C6}$ ), and $10 \pm 1.1 \mathrm{mmol} \mathrm{LA} / \mathrm{L}$ [41].

To enhance $\mathrm{H}_{2}$ production, several experiments were carried out by combining different amounts of onion waste $(0-200 \mathrm{~mL})$ and $100 \mathrm{~mL}$ of other fruit and vegetable waste (FVW). The increase in onion waste levels significantly improved substrate consumption $(69.8 \%$ without $\mathrm{OW}$ and $79 \%$ with $200 \mathrm{~mL}$ of $\mathrm{OW}), \mathrm{H}_{2}$ yield $\left(3.24 \pm 0.5 \mathrm{~mol} \mathrm{H}_{2} / \mathrm{mol}\right.$ $\mathrm{C} 6$ without $\mathrm{OW}$ and $3.75 \pm 0.8 \mathrm{~mol} \mathrm{H}_{2} / \mathrm{mol} \mathrm{C} 6$ with $200 \mathrm{~mL}$ of $\mathrm{OW}$ ), and acetate yield (1.67 mol AA/mol C6 without OW and $1.99 \mathrm{~mol} \mathrm{AA} / \mathrm{mol} \mathrm{C6}$ with $200 \mathrm{~mL}$ of OW) [41]. An economical and efficient $\mathrm{H}_{2}$ production process was finally obtained by the removal of inorganic nitrogen sources and a surplus of onion waste $(400 \mathrm{~mL})$ (Table 2) [41].

\subsubsection{Fish Waste}

Supplemented of fish waste (FW) can be used to overcome the low nitrogen content in fruit and vegetable waste to sustain T. maritima cultures [40]. The fish waste from sardines 
represents a highly biodegradable product. It is available in large quantities and rich in nitrogen, making it a good candidate to balance the $\mathrm{C} / \mathrm{N}$ ratios in growth media. The reduction of $\mathrm{C} / \mathrm{N}$ ratio by increasing fish waste counterparts (range $0-250 \mathrm{~mL}$ ) significantly enhanced substrate consumption (from $69.85 \%$ at $47 \mathrm{C} / \mathrm{N}$ ratio to $96 \%$ at $12 \mathrm{C} / \mathrm{N}$ ratio), $\mathrm{H}_{2}$ yield (from $3.24 \pm 0.1$ at $47 \mathrm{C} / \mathrm{N}$ ratio to $3.87 \pm 0.1$ at $12 \mathrm{C} / \mathrm{N}$ ratio), and organic acids production (AA: $56 \pm 1.5 \mathrm{mmol} / \mathrm{L}$ at $47 \mathrm{C} / \mathrm{N}$ ratio to $99.5 \pm 2.6 \mathrm{mmol} / \mathrm{L}$ at $12 \mathrm{C} / \mathrm{N}$ ratio; LA: $10.1 \pm 1.1 \mathrm{mmol} / \mathrm{L}$ at $47 \mathrm{C} / \mathrm{N}$ ratio to $33.4 \pm 2.9 \mathrm{mmol} / \mathrm{L}$ at $47 \mathrm{C} / \mathrm{N}$ ratio) [40]. In this example, a net increase of $\mathrm{H}_{2}$ production was observed, resulting in $285 \pm 2.9 \mathrm{mmol} / \mathrm{L}$ of $\mathrm{H}_{2}$ (yield of $3.86 \mathrm{~mol} \mathrm{H}_{2} / \mathrm{mol}$ hexose) with $148 \pm 3.5 \mathrm{mmol} / \mathrm{L}$ of AA (yield of $1.94 \mathrm{~mol}$ $\mathrm{AA} / \mathrm{mol} \mathrm{C6}$ ) and $49 \pm 1.3 \mathrm{mmol} / \mathrm{L}$ of LA (Table 2) [40].

\subsubsection{Rice straw}

Rice straw is produced as a by-product of rice production, and represents one of the major lignocellulosic industrial residues in the world [100]. It is the vegetative part of the rice plants (Oryza sativa L.), cut at grain harvest or after. It may be burned, ploughed down as a soil improver, used as a feed for livestock or to produce biofuels such as bioethanol [101]. It is composed of $41.4 \%$ cellulose, $19.6 \%$ hemicellulose, $22.8 \%$ total lignin (3\% acid-soluble lignin and $19.8 \%$ acid-insoluble lignin), and $10.9 \%$ ash [102]. Over the years, different chemical pretreatments (e.g., thermal $\mathrm{NH}_{3}$, thermal dilute $\mathrm{H}_{2} \mathrm{SO}_{4}$, combined pretreatments) were investigated to improve the conversion of residues to fermentable compounds, thus improving their utility in anaerobic digestion [103-105]. Korean rice straw has been used as a growth substrate for T. neapolitana [102]. To reduce the percentage of lignin in the matrix and to release the more accessible sugars contained in the cellulose and hemicellulose, a combined protocol consisting of two steps was proposed [102,106,107]. Rice straw particles and $10 \%$ ammonium hydroxide solution were thoroughly mixed and autoclaved at $121{ }^{\circ} \mathrm{C}$ for $60 \mathrm{~min}$. Then the water-washed solid fractions were hydrolyzed with $1.0 \%$ sulfuric acid under autoclaving condition at $121^{\circ} \mathrm{C}$ for $50 \mathrm{~min}$, and the hydrolysate mixture was finally neutralized by $5 \mathrm{~N}$ of $\mathrm{NaOH}$ solution before its use as a carbon source [102,107]. After hydrolysis, the solid fraction consisted of $62.6 \%$ glucose, $3.04 \%$ xylose, and $5.29 \%$ lignin, whereas the liquid fraction was composed of $3.93 \%$ glucose and $16.16 \%$ xylose. Moreover, $78 \%$ of the lignin was removed, and an effective hemi-cellulose hydrolysis of $81.6 \%$ was observed. The liquid fraction was then used for the fermentation: $85.4 \%$ of the rice straw was consumed, including $95.7 \%$ of the xylose conversion and $73.0 \%$ of the glucose conversion. $\mathrm{H}_{2}$ production was $112.38 \pm 7.66 \mathrm{~mL} / \mathrm{L}$, with a yield of $2.7 \mathrm{mmol}$ $\mathrm{H}_{2} / \mathrm{g}$ straw (Table 2) [102]. Compared with the untreated form (not shown) and other chemical pretreatments, hydrogen production was noticeably increased, demonstrating that the combination of an efficient pretreatment and the capability of T. neapolitana to completely metabolize glucose and xylose can offer many advantages in rice straw valorization. Inhibitory effects on the growth rate due to chemical reagents used in the hydrolytic treatment should be overcome for industrial exploitation of this process. 
Table 2. Fermentation of food waste by Thermotoga spp.

\begin{tabular}{|c|c|c|c|c|c|c|c|c|c|c|c|c|c|c|c|}
\hline Substrate & $\begin{array}{c}\text { Matrix } \\
\text { Components }\end{array}$ & $\begin{array}{c}\text { Sugar } \\
\text { Components }\end{array}$ & $\begin{array}{c}\text { Pretreatment } \\
\text { Type }\end{array}$ & $\begin{array}{l}\text { Pretreatment } \\
\text { Method }\end{array}$ & $\begin{array}{l}\text { Substrate } \\
\text { Load } \\
(\mathrm{g} / \mathrm{L})\end{array}$ & Strain & $\begin{array}{c}\mathrm{T} \\
\left({ }^{\circ} \mathrm{C}\right)\end{array}$ & $\begin{array}{c}\text { Start } \\
\text { pH }\end{array}$ & $\begin{array}{c}\text { Mixing } \\
\text { Speed } \\
(\mathrm{rpm})\end{array}$ & $\begin{array}{l}\text { Volume } \\
\text { tot. }(\mathrm{mL})\end{array}$ & $\begin{array}{c}\text { Working } \\
\text { Volume } \\
(\mathrm{mL})\end{array}$ & $\begin{array}{c}\mathrm{H}_{2} \text { yield } \\
\text { (mol/mol } \\
\text { sugar) }\end{array}$ & $\begin{array}{c}\text { Organic } \\
\text { Acids } \\
\text { Yield } \\
\text { (mol/mol } \\
\text { sugar) }\end{array}$ & $\begin{array}{c}\text { Organic } \\
\text { Acids } \\
(\mathrm{g} / \mathrm{L})\end{array}$ & Ref. \\
\hline \multirow{2}{*}{$\begin{array}{l}\text { Carrot } \\
\text { pulp }\end{array}$} & \multirow{2}{*}{$\begin{array}{l}\text { Glucose, fructose, } \\
\text { sucrose, } \\
\text { polysaccharides }\end{array}$} & \multirow{2}{*}{$\begin{array}{l}\text { Glucose, } \\
\text { fructose }\end{array}$} & \multirow{2}{*}{ Enzymatic } & \multirow{2}{*}{ Enzymes } & \multirow{2}{*}{10} & \multirow{2}{*}{ T.nea } & \multirow{2}{*}{72} & \multirow{2}{*}{$6.8 / 7$} & \multirow{2}{*}{350} & \multirow{2}{*}{2000} & \multirow{2}{*}{1000} & 2.7 & $\begin{array}{l}\text { AA } 1.3 \\
\text { LA } 0.17\end{array}$ & $\begin{array}{l}\text { AA } 7.20 \\
\text { LA } 1.34\end{array}$ & \multirow{2}{*}{ [75] } \\
\hline & & & & & & & & & & & & 2.4 & $\begin{array}{c}\text { AA } 1.1 \\
\text { LA } 0.30\end{array}$ & $\begin{array}{l}\text { AA } 10.79 \\
\text { LA } 4.08\end{array}$ & \\
\hline \multirow{4}{*}{$\begin{array}{l}\text { Rice } \\
\text { straw }\end{array}$} & \multirow{4}{*}{$\begin{array}{l}\text { Cellulose, } \\
\text { hemicellulose, } \\
\text { lignin }\end{array}$} & \multirow{4}{*}{$\begin{array}{l}\text { Glucose, } \\
\text { xylose }\end{array}$} & Untreated & - & \multirow{4}{*}{10} & \multirow{4}{*}{ T.nea } & \multirow{4}{*}{75} & \multirow{4}{*}{7.5} & \multirow{4}{*}{150} & \multirow{4}{*}{120} & \multirow{4}{*}{40} & $2.27 \pm 0.01$ & \multirow{4}{*}{ - } & \multirow{4}{*}{ - } & \multirow{4}{*}{ [102] } \\
\hline & & & \multirow{3}{*}{ Chemical } & $\mathrm{NH}_{3}$ & & & & & & & & $2.68 \pm 0.02$ & & & \\
\hline & & & & $\mathrm{H}_{2} \mathrm{SO}_{4}$ & & & & & & & & $2.61 \pm 0.01$ & & & \\
\hline & & & & $\begin{array}{c}\text { Combined } \\
\mathrm{NH}_{3} / \mathrm{H}_{2} \mathrm{SO}_{4}\end{array}$ & & & & & & & & $2.70 \pm 0.01$ & & & \\
\hline $\begin{array}{l}\text { Potato } \\
\text { steam } \\
\text { peels }\end{array}$ & Starch & Glucose & Enzymatic & Enzymes & 10 & T.nea & 75 & 6.9 & 350 & 2000 & 1000 & 3.8 & $\begin{array}{l}\text { AA } 1.8 \\
\text { LA } 0.20\end{array}$ & - & [95] \\
\hline Molasses & $\begin{array}{l}\text { Glucose, } \\
\text { fructose, } \\
\text { sucrose }\end{array}$ & $\begin{array}{l}\text { Glucose, } \\
\text { fructose, } \\
\text { sucrose }\end{array}$ & - & - & 20 & T.nea & 77 & 8.5 & 100 & 116 & 40 & $2.6 \pm 0.1$ & AA 1.5 & - & [38] \\
\hline $\begin{array}{l}\text { Cheese } \\
\text { whey }\end{array}$ & $\begin{array}{l}\text { Lactose, proteins, } \\
\text { lipids }\end{array}$ & Lactose & - & - & 12.5 & T.nea & 77 & 8.5 & 100 & 116 & 40 & $2.4 \pm 0.1$ & AA 1.0 & - & \\
\hline \multirow{2}{*}{$\begin{array}{l}\text { Fruit and } \\
\text { vegetable } \\
\text { waste }\end{array}$} & \multirow{2}{*}{$\begin{array}{c}\text { Cellulose, } \\
\text { hemicellulose }\end{array}$} & \multirow[b]{2}{*}{ Glucose } & \multirow[b]{2}{*}{ Mechanical } & \multirow[b]{2}{*}{ Shredding } & 8.1 & \multirow[b]{2}{*}{ T.mar } & & & & 2200 & & 3.89 & AA 1.96 & AA 5.39 & [39] \\
\hline & & & & & $\begin{array}{c}20 \\
\text { (plus FW) }\end{array}$ & & 80 & 7 & 150 & 2500 & 1100 & 3.86 & AA 1.94 & $\begin{array}{c}\text { AA } 12.28 \\
\text { LA } 5.49\end{array}$ & [40] \\
\hline Onion & Glucose, fructose, & Glucose, & Mechanical & Shredding & $200 * \mathrm{OW}$ & Tmar & 80 & 7 & 150 & 2500 & 1100 & $3.76 \pm 0.5$ & AA 1.97 & $\begin{array}{l}\text { AA } 5.33 \\
\text { LA } 1.12 \\
\end{array}$ & {$[41]$} \\
\hline waste & $\begin{array}{l}\text { sucrose, cellulose, } \\
\text { hemicellulose }\end{array}$ & $\begin{array}{l}\text { fructose, } \\
\text { sucrose }\end{array}$ & & & $\begin{array}{c}400 * \text { OW } \\
100 * \text { FVW }\end{array}$ & & & & & & & $3.67 \pm 0.8$ & AA 1.85 & $\begin{array}{l}\text { AA } 9.27 \\
\text { LA } 1.96\end{array}$ & \\
\hline
\end{tabular}

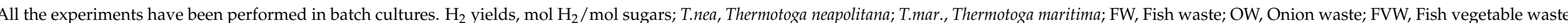
Substrate load column: * mL. 


\subsubsection{Molasses}

Molasses is one of the main products of the sugar cane or sugar beet industry, commonly used to produce alcohol and food flavoring. It is mainly composed of glucose, fructose and sucrose, and high amounts of organic nitrogen, vitamins and salts [108-112]. It can be employed without any pretreatments, avoiding additional nitrogen sources like yeast extract and peptone in hydrogen production by fermentative bacteria [111]. T. neapolitana, T. maritima, T. naphtophila and T. petrophila were able to produce $\mathrm{H}_{2}$ from molasses with both suspended and immobilized cells, and in particular T. neapolitana showed comparable yields to pure glucose under the same conditions [38]. The fermentation process in complete medium leads to efficient $\mathrm{H}_{2}$ production of $2.6 \pm 0.1 \mathrm{~mol} \mathrm{H}_{2} / \mathrm{mol} \mathrm{C} 6$ and acetic acid production of $1.5 \mathrm{~mol} \mathrm{AA} / \mathrm{mol} \mathrm{C6}$ (Table 2) [38]. The removal of vitamins, micronutrients, tryptic soy broth, yeast extract, $\mathrm{MgCl}_{2}$, and $\mathrm{CaCl}_{2}$ from the growth medium of T. neapolitana achieved a $70 \%$ reduction of medium cost, without significant loss of performance in molasses fermentation ( $2.95 \pm 0.09 \mathrm{~mol} \mathrm{H}_{2} / \mathrm{mol} \mathrm{C} 6$ and $\left.1.0 \mathrm{~mol} \mathrm{AA} / \mathrm{mol} \mathrm{C6}\right)$ [38]. These findings were confirmed by Frascari et al., who developed a kinetic model of biohydrogen production by molasses fermentation in T. neapolitana, in which several parameters were considered as fundamental to further optimize the fermentation process, such as the effects of $\mathrm{H}_{2}, \mathrm{O}_{2}$ and substrate inhibition [113].

\subsubsection{Cheese Whey}

Cheese whey is the wastewater originating from the precipitation and removal of milk casein during cheese-making. It represents a renewable resource in the food industry for its high lactose content. The milk type used in the cheese production (cow, goat, sheep, buffalo, and other mammals) influences the characteristics of the produced cheese whey. For example, bovine whey contains $70-80 \%$ lactose, $9 \%$ proteins, $8-20 \%$ minerals and other minor components, such as some hydrolyzed peptides of k-casein, lipids and bacteria [114]. Due to its high organic content, it cannot be directly discharged into water bodies and is not easily treatable in municipal/consortium purification plants, thus becoming an environmental problem for the dairy industry [115]. Cheese whey is commonly used as direct animal feed, or to be produced as protein and lactose powders for human food and livestock feed. Biological treatment involving the microbial conversion of the lactose contained in cheese whey represents one of the best approaches to obtain value-added products, such as organic acids, bioalcohols, gases (e.g., hydrogen, methane) and bioplastics [116]. Cheese whey was evaluated as the substrate for selected Thermotoga spp. (T. neapolitana, T. maritima, T. naphtophila and T. petrophila) to better resist high $\mathrm{H}_{2}$ concentrations [38]. In terms of $\mathrm{H}_{2}$ production rate, T. neapolitana was markedly superior to the other three strains, obtaining $2.4 \pm 0.1 \mathrm{~mol} \mathrm{H}_{2} / \mathrm{mol}$ glucose eq. in complete medium (Table 2). The use of minimal medium supported neither growth nor $\mathrm{H}_{2}$ production of $T$. neapolitana, probably because the protein content of the cheese whey was not readily usable [38]. Kinetic studies in Frascari et al. showed that immobilized and suspended cells performed similarly in cheese whey-based reactors [113].

\subsection{Lignocellulosic Waste}

Lignocellulosic waste arises from agricultural and wood industries, and represent the largest renewable feedstock for industrial fermentation [117-124]. Lignocellulosic materials are composed of heterogeneous polysaccharides derived from the photosynthesis process representing a potentially inexpensive carbon source of hexose and pentose sugars. More than $90 \%$ of plant dry weight is composed of cellulose (30-60\%) and hemicelluloses $(20-40 \%)$. Cellulose is a complex carbohydrate consisting of monomeric glucose units, and hemicelluloses are polysaccharides consisting of different pentose and hexose sugars units (mainly xylose, arabinose, glucose, and galactose). Cellulose and hemicelluloses form the structural components of plant cell walls, providing mechanical resistance and protection against pathogens. They tightly bound to lignin (10-25\%), which is a class of cross-linked polymers rich in aromatic subunits, relatively hydrophobic and heterogeneous, with differ- 
ent degrees of polymerization $[120,125,126]$. The major hurdle in the industrial exploitation of lignocellulosic waste as an energy feedstock comes from the need to first hydrolyze them and then remove the lignin from the cellulose and hemicellulose by economical and efficient processes $[122,123,126,127]$. Due to its hydrophobic and heterogeneous nature, lignin is resistant to acid and base hydrolysis, representing an obstacle for accessing the fermentable polysaccharides for biogas production. Moreover, lignin contains certain oligosaccharides and phenolic compounds that can act as growth inhibitors, representing another significant obstacle during the degradation of the cell walls [10,126,128].

Several chemical, physical, biochemical, and biological pretreatments have been proposed over the years to increase the biodegradation of lignocellulosic compounds and release their fermentable parts $[10,42,44,81,118,126,129-131]$. Hyperthermophilic bacteria are known to ferment the lignocellulosic biomass because they contain many relevant thermostable glycoside hydrolases $[10,61,86,130]$. The high growth temperatures also promote partial detachment of lignin from the hemicellulose-cellulose assembly and the degradation of growth inhibitors [81,129,130,132].

\subsubsection{Miscanthus Waste}

Miscanthus is a woody rhizomatous $\mathrm{C} 4$ perennial grass which represents an advantageous lignocellulosic energy crop adapted to various bioenergy processes, replacing fossil fuel resources. It combines high biomass production per hectare in various climates, suitable biomass composition for various thermochemical or biochemical conversions, and a positive environmental footprint (lowest water requirement, lowest $\mathrm{N}, \mathrm{P}$, and $\mathrm{K}$ fertilization, low greenhouse gas emissions, low invasiveness, etc.) [133]. About $62.5 \%$ of the total dry matter consists of cellulose and hemicellulose, whose main components are glucans and xylans. The total lignin content of the grass is around $25.0 \%$, consisting mainly of acid-insoluble compounds, which makes a pretreatment step mandatory $[129,130]$.

There have been several studies comparing different pretreatments to make Miscanthus biomass fermentable by Thermotoga spp. In early studies on P. elfii, the best Miscanthus hydrolysate was obtained involving a combination of mechanical extrusion and incubation with sodium hydroxide. The pretreatment caused a substantial delignification of the biomass and significantly improved $\mathrm{C} 5$ and $\mathrm{C} 6$ sugars, reaching a final monosaccharide concentration around $32 \mathrm{~g} / \mathrm{L}$ in the hydrolysate [129]. P. elfii could grow on Miscanthus hydrolysates, consuming glucose and xylose simultaneously, and reaching high hydrogen $(82.2 \mathrm{mM})$ and acetic acid $(42.4 \mathrm{mM})$ production, even slightly higher than growing on glucose [129]. The Miscanthus fermentation was also demonstrated in T. neapolitana cultures [130]. Based on the previous work, different alkali pretreatments were investigated to reduce lignin insoluble fractions in the hydrolysates. The $\mathrm{NaOH}$ incubation at $85^{\circ} \mathrm{C}$ for $16 \mathrm{~h}$ was found to be the optimal condition. Afterwards, enzymatic hydrolysis with cellulases was performed at $50{ }^{\circ} \mathrm{C}$ for $24 \mathrm{~h}$ to facilitate the release of arabinose, glucose, and xylose. T. neapolitana grown on $14 \mathrm{~g} / \mathrm{L}$ of hydrolysate gave $3.2 \mathrm{~mol} \mathrm{H}_{2} / \mathrm{mol} \mathrm{C} 6,1.4 \mathrm{~mol} \mathrm{AA} / \mathrm{mol}$ C6, and $11.2 \mathrm{mmol} \mathrm{LA} / \mathrm{L}$ (Table 3), demonstrating the efficiency of these pretreatment steps in Thermotoga spp. fermentation [130]. When hydrolysate concentrations exceeding $28 \mathrm{~g} / \mathrm{L}$, the $\mathrm{H}_{2}$ and acetate yields substantially dropped to $2.0 \mathrm{~mol} \mathrm{H}_{2} / \mathrm{mol} \mathrm{C} 6$ and $1.1 \mathrm{~mol}$ $\mathrm{AA} / \mathrm{mol} \mathrm{C6}$, since the fermentability of the substrate was reduced [130].

\subsubsection{Garden Waste}

Garden and park waste are generated from the maintenance of private gardens and public parks, and represent an economic substrate to produce biohythane (a mixture of hydrogen and methane, usually with 10 to $25 \%$ hydrogen in volume) and hydrogen via anaerobic dark fermentation $[77,134,135]$. In general, we can identify three major components: an organic fraction from garden grass, small bushes containing an undefined organic content and inorganic elements (on a dry matter basis, $0.6 \% \mathrm{~N}, 0.1 \% \mathrm{P}$, and $1.0 \% \mathrm{~K}$ ), and ash, whose content is related to the amount of soil present. On an annual base, wet 
garden waste contains $40 \%$ water, $30 \%$ organic matter, $30 \%$ ash, and a low content of trace elements (Cd, Cr, Cu, Hg, $\mathrm{Ni}, \mathrm{Pb}$, and $\mathrm{Zn}$ ) [136].

Abreu et al. [77] estimated biohydrogen production by T. maritima from garden waste with a glucans/xylans ratio of 3:1 and a lignin content higher than 30\% [77]. To develop a sustainable process, the biomass was homogenized, and no harsh chemical pretreatments were performed. $\mathrm{H}_{2}$ production from garden waste by T. maritima reached $45.1 \pm 4.6 \mathrm{~L}$ of $\mathrm{H}_{2}$ per $\mathrm{Kg}$ of organic matter with $3.8 \pm 0.2 \mathrm{mmol} / \mathrm{L}$ of AA (Table 3) [77]. These results were not very encouraging in comparison to data obtained using pure sugars, suggesting the inability of T. maritima to ferment the more recalcitrant fraction of the garden waste. Therefore, efficient pretreatments are needed to make the waste more accessible to fermentation.

\subsubsection{Paper Sludge}

Paper sludge is a solid industrial waste, arising from the paper industry which can be partially used in cement as a Supplementary Material $[137,138]$. Landfilling and incineration are also common handling options. However, companies from different sectors are looking for new solutions to reduce costs and their impact on the environment. Wastepaper sludge is becoming an economical and profitable material that can be used, after hydrolysis, in green technologies; for example, as a substrate for microbial fermentation to obtain hydrogen. This is due to its chemical and mineralogical composition: besides its low sulfate content, it is rich in minerals (calcium, silicon and aluminum etc.), proteins (22-52\%), lignin $(20-58 \%)$, carbohydrates $(0-23 \%)$, lipids $(2-10 \%)$, and cellulose (2-8\%) [139]. The first example of paper sludge fermentation was reported for P. elfii [137]. The hydrolysate was obtained after digestion for $48 \mathrm{~h}$ using a chemical-enzymatic approach involving $\mathrm{H}_{2} \mathrm{SO}_{4}$, resulting in $12.8 \mathrm{~g} / \mathrm{L}$ of glucose and $2.4 \mathrm{~g} / \mathrm{L}$ of xylose [137]. To search for the medium components for optimal hydrogen production, the bacterium was cultivated in different conditions with defined and complex media. Data demonstrated that $P$. elfii grew on paper sludge hydrolysate. In complex medium, hydrogen production, sugar consumption and acetate production rates were similar to glucose fermentation (approximately $30 \mathrm{mM}^{\circ} \mathrm{H}_{2}$, $15 \mathrm{mM}$ of glucose consumption, $15 \mathrm{mM}$ of AA and less than $5 \mathrm{mM}$ of LA on paper sludge). Only a slight reduction in hydrogen production was observed without salts (less than $20 \mathrm{mM}$ of $\mathrm{H}_{2}$ ), while a net decrease in both hydrogen and acetate production, together with the glucose consumption rate (approximately $11 \mathrm{mM}$ of $\mathrm{H}_{2}$ and $7 \mathrm{mM}$ of AA with $6 \mathrm{mM}$ of glucose consumed) was observed without yeast extract, indicating that this component was essential for optimal results [137]. The hydrogen production rate on paper sludge hydrolysate was around $48 \%$ of the theoretical hydrogen yield of $4 \mathrm{~mol}$ of hydrogen $/ \mathrm{mol}$ of C6 sugar, suggesting that there were still possibilities to improve the biomass pretreatments and cultural conditions to utilize this waste (Table 3) [137]. 
Table 3. Fermentation of lignocellulosic waste and microalgal biomass by Thermotogaceae.

\begin{tabular}{|c|c|c|c|c|c|c|c|c|c|c|c|c|c|c|}
\hline Substrate & $\begin{array}{c}\text { Matrix } \\
\text { Components }\end{array}$ & $\begin{array}{c}\text { Sugar } \\
\text { Components }\end{array}$ & $\begin{array}{c}\text { Pretreatment } \\
\text { type }\end{array}$ & $\begin{array}{l}\text { Pretreatment } \\
\text { Method }\end{array}$ & $\begin{array}{l}\text { Substrate } \\
\text { Load } \\
(\mathrm{g} / \mathrm{L})\end{array}$ & Strain & $\begin{array}{c}\mathrm{T} \\
\left({ }^{\circ} \mathrm{C}\right)\end{array}$ & $\begin{array}{l}\text { Start } \\
\mathrm{pH}\end{array}$ & $\begin{array}{l}\text { Mixing } \\
\text { Speed } \\
(\mathrm{rpm})\end{array}$ & $\begin{array}{c}\text { Volume } \\
\text { tot. } \\
(\mathrm{mL})\end{array}$ & $\begin{array}{l}\text { Working } \\
\text { Volume } \\
\text { (mL) }\end{array}$ & $\begin{array}{c}\mathrm{H}_{2} \text { Yield } \\
\text { (mol/mol } \\
\text { sugars) }\end{array}$ & $\begin{array}{c}\text { Organic } \\
\text { Acid(g/L) }\end{array}$ & Ref. \\
\hline \multirow{2}{*}{ Miscanthus } & \multirow{2}{*}{$\begin{array}{l}\text { Cellulose, } \\
\text { hemicellulose, } \\
\text { lignin }\end{array}$} & \multirow{2}{*}{$\begin{array}{l}\text { Glucose, } \\
\text { xylose }\end{array}$} & $\begin{array}{l}\text { Mechanical, } \\
\text { chemical }\end{array}$ & $\begin{array}{c}\text { Extrusion } \\
\mathrm{NaOH}\end{array}$ & 14 & T.nea & 80 & 7 & 350 & 2000 & 1000 & 3.2 & $\begin{array}{c}\text { AA } 10.29 \\
\text { LA } 1.25\end{array}$ & [130] \\
\hline & & & $\begin{array}{l}\text { Chemical, } \\
\text { enzymatic }\end{array}$ & $\begin{array}{c}\mathrm{NaOH} \\
\text { enzymes }\end{array}$ & 10 & P.elfii & 65 & 8 & - & 100 & 30 & $60.36^{*}$ & AA 3.52 & [129] \\
\hline $\begin{array}{l}\text { Garden } \\
\text { waste }\end{array}$ & $\begin{array}{l}\text { Glucans, } \\
\text { Xylans, } \\
\text { lignin }\end{array}$ & $\begin{array}{l}\text { Glucans, } \\
\text { xylans }\end{array}$ & Mechanical & Shredding & 5 & T.mar & 70 & 7.2 & 90 & 120 & 50 & $41.5^{* *}$ & AA 0.31 & [77] \\
\hline $\begin{array}{l}\text { Paper } \\
\text { sludge }\end{array}$ & $\begin{array}{c}\text { Proteins, lignin, } \\
\text { carbohydrates, } \\
\text { lipids, cellulose }\end{array}$ & $\begin{array}{l}\text { Glucose, } \\
\text { xylose }\end{array}$ & $\begin{array}{l}\text { Chemical, } \\
\text { enzymatic }\end{array}$ & $\begin{array}{l}\mathrm{H}_{2} \mathrm{SO}_{4}^{-} \\
\text {enzymes }\end{array}$ & 11 & P.elfii & 65 & 7.2 & 100 & 30 & - & - & - & [137] \\
\hline $\begin{array}{c}\text { Chlamydomonas } \\
\text { reinhardtii }\end{array}$ & Starch & Glucose & Enzymatic & Enzymes & 5 & T.nea & 75 & $7 / 7.4$ & 150 & 120 & 40 & $2.5 \pm 0.3$ & - & [140] \\
\hline $\begin{array}{l}\text { Thalassiosira } \\
\text { weissflogi }\end{array}$ & $\begin{array}{l}\text { Protein, chryso- } \\
\text { laminarins }\end{array}$ & Chrysolaminarins & Chemical & $\mathrm{MeOH}$ & 2 & T.nea & 80 & $7.5 / 8$ & 250 & 3800 & 500 & $1.9 \pm 0.1$ & $\begin{array}{l}\text { AA } 1.57 \\
\text { LA } 0.112\end{array}$ & [141] \\
\hline
\end{tabular}

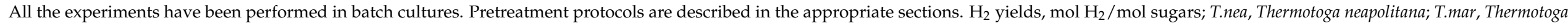
maritima; P. elfii, Pseudothermotoga elfii. $\mathrm{H}_{2}$ yield column: ${ }^{*} \mathrm{~mL} / \mathrm{L} ;{ }^{* *} \mathrm{~L} / \mathrm{Kg}$. 


\subsection{Glycerol}

Crude glycerol is the major by-product of the biodiesel industry, generated by basecatalyzed transesterification during the biodiesel production processes [142]. It represents a green, biodegradable and abundant feedstock that can be widely used in pharmaceuticals, cosmetics, soaps, toothpastes, paints, and other commercial products [71,143]. Since around $1 \mathrm{~kg}$ of glycerol waste is generated for every $10 \mathrm{~kg}$ of biodiesel produced, its abundance has increased due to the dramatic growth of the biodiesel industry, although its economic value has decreased in the last few years [142]. Developing advanced sustainable systems is essential to a wider range of applications of crude glycerol without increasing the refining costs [144]. The classical refining processes, such as filtration, chemical additions, and fractional vacuum distillation are sometimes too expensive for small and middle-sized producers $[145,146]$. From this perspective, economic and alternative ways of using crude glycerol have been studied, like fatty acid production, animal feed, biological conversion [144,146-150]. Among these options, anaerobic digestion to biogas (e.g., methane and hydrogen) production from fermentative microorganisms represents a promising approach, which produces high levels of biogas in small reactors and enjoys several advantages, such as low nutrient requirements, energy savings, and generation of a stabilized digestate [142-144,151]. The chemical compositions of crude glycerol are not well defined and are dependent on the parent feedstock and biodiesel production processes, e.g., the type of catalyst used, the transesterification efficiency, recovery efficiency of the biodiesel and other impurities [144,146]. Generally, every feedstock contains around $50-60 \%$ (wt) of glycerol, 12 to $16 \%$ of alkalis, especially in the form of alkali soaps and hydroxides, 15 to $18 \%$ of methyl esters, 8 to $12 \%$ of methanol, and 2 to $3 \%$ of water [146]. In addition to methanol and soaps, crude glycerol also contains $\mathrm{Ca}, \mathrm{Mg}$, $\mathrm{P}$, or S [146], K, Na, C, N, and proteins (0.05 to $0.44 \%$ ), etc. [142]. The impurities present in the raw substrate, such as spent catalysts, salts after neutralization, residual methanol, methyl esters, oil/fat, soap and free fatty acids, have to be removed to make the substrate suitable for further applications [146,152]. As a carbon source, glycerol was tested for biohydrogen production via anaerobic fermentation by thermophilic bacteria. Since glycerol is a more reduced compound compared to other substrates like glucose or xylose, it has the potential to generate more NADH and $\mathrm{H}_{2}$ during catabolism [153].

Some controversies exist concerning the ability of Thermotogaceae family members to utilize glycerol. Early studies reported that $T$. maritima contained the coding sequences for a complete pathway for glycerol uptake, although glycerol had to enter into the cell by diffusion in other strains (e.g., T. neapolitana), [154-156]. Therefore, a putative degradation pathway based on the T. maritima genome was proposed, i.e., glycerol enters the cell either by diffusion or facilitated transportation and enters glycolysis via glycerol-3-phosphate. The involvement of a glycerol kinase and an uncharacterized NAD+ or FAD-dependent multimeric glycerol-3-phosphate dehydrogenase has been hypothesized [154].

Two research groups experimented with the possibility of fermenting glycerol in T. maritima, T. neapolitana, and P. elfii, obtaining conflicting results. Eriksen et al. observed growth only if glycerol was supplemented simultaneously with one or more sugars; none of the three species grew if glycerol was the sole carbon source (data not shown) [36]. The surplus of NADH generated during glycerol conversion may influence the activity of the bifurcating hydrogenases present in these bacteria. In fact, $2 \mathrm{~mol}$ of NADH and $2 \mathrm{~mol}$ of reduced ferredoxin were produced in glycerol conversion, changing the conventional stoichiometric ratio for hydrogenase activity from 1:2 to 1:1 [153,157,158].

The capability of $T$. neapolitana to ferment glycerol waste was also demonstrated by Ngo et al. [151]. Before use, crude glycerol waste was pretreated to avoid inhibition of bacterial growth by removing the solvents present (e.g., methanol and/or ethanol) by rotary evaporation at $45^{\circ} \mathrm{C}$, and the solid fraction was precipitated by centrifugation at $15,000 \mathrm{rpm}$ for $15 \mathrm{~min}$ [151]. $\mathrm{H}_{2}$ yield was around $1.97 \pm 0.09 \mathrm{~mol} \mathrm{H}_{2} / \mathrm{mol}$ glycerol, obtained without any other modification. Several cultural parameters were also important to enhance glycerol fermentation, including $\mathrm{pH}, \mathrm{N}_{2}$ sparging, sodium chloride concentration and yeast 
extract. Under specific conditions (i.e., $\mathrm{N}_{2}$ sparging and buffering agent), $\mathrm{H}_{2}$ could reach $2.7 \pm 0.1 \mathrm{~mol} \mathrm{H}_{2} / \mathrm{mol}$ glycerol; considerable production of acetic acid was also observed $(22.35 \pm 1.05 \mathrm{mmol} / \mathrm{L})$ (Table 4) [151]. Another study [71] confirmed this ability with pure and waste glycerol, obtaining $1.3 \pm 0.06 \mathrm{~mol} \mathrm{H}_{2} / \mathrm{mol}$ of glycerol waste consumed and a percentage of acetic and lactic acid comparable to pure glycerol results (data not shown) [71]. During fermentation, more acetic acid than lactic acid was produced, implying that the $\mathrm{H}_{2}$-acetate pathway predominated over the lactate one [70].

Again, in the study of Maru et al. [153], both T. neapolitana and T. maritima metabolized pure glycerol and produced $\mathrm{H}_{2}$ at $2.65 \mathrm{~mol} \mathrm{H}_{2} / \mathrm{mol}$ glycerol for T. neapolitana and $2.75 \mathrm{~mol}$ $\mathrm{H}_{2} /$ mol glycerol for T. maritima (Table 4) [153]. In order to improve glycerol fermentation, cultural conditions were optimized in T. maritima by testing the glycerol content, yeast extract concentration, and $\mathrm{pH}$ control. Maximum $\mathrm{H}_{2}$ yields were $2.86 \mathrm{~mol} \mathrm{\textrm {H } _ { 2 }} / \mathrm{mol}$ glycerol for T. neapolitana and $2.84 \mathrm{~mol} \mathrm{H}_{2} / \mathrm{mol}$ glycerol for T. maritima in the optimized conditions [154].

\subsection{Microalgal Biomass}

Microalgae are photosynthetic unicellular organisms living individually, in chains or groups in a wide range of aquatic habitats; they can tolerate different light intensities, temperature, salinity and $\mathrm{pH}$ values [159]. They can be cultured in large scale by different methods and conditions, and represent a potential feedstock for the coproduction of different forms of energy. Several species were recently investigated as a fuel source since they contain large quantities of lipids useful for biodiesel production $[159,160]$. For example, marine diatoms contain up to $50 \%$ of lipids per biomass dry weight [161]. Moreover, to valorize all microalgal biomass components, the soluble polysaccharides of photosynthetic biomass could play an important role for biohydrogen production through DF [140].

T. neapolitana can metabolize different microalgal biomass. Nguyen et al. [140] and Dipasquale et al. [141] studied T. neapolitana fermentation on the biomasses of Chlamydomonas reinhardtii and Thalassiosira weissflogi respectively [140,141]. In the former case, algal biomass was pretreated in two different ways (heat- $\mathrm{HCl}$ and Termamyl enzyme) to disrupt the algal cell walls and release starch for fermentation [140]. Termamyl enzyme pretreatment, performed by a thermostable $\alpha$-amylase from Bacillus licheniformis at $90^{\circ} \mathrm{C}$ for $30 \mathrm{~min}$, was the most effective process to optimize the hydrolysis [140]. This pretreatment maximized $\mathrm{H}_{2}$ yield $\left(2.5 \pm 0.3 \mathrm{~mol} \mathrm{H}_{2} / \mathrm{mol}\right.$ glucose eq) when compared to that obtained with other pretreatment methods $\left(<2.2 \mathrm{~mol} \mathrm{H}_{2} / \mathrm{mol}\right.$ glucose eq) or with pure starch fermentation ( $1.5 \pm 0.1 \mathrm{~mol} \mathrm{H}_{2} / \mathrm{mol}$ glucose eq) (Table 3) [140].

In the latter study [141], chemical extraction with $\mathrm{MeOH}$ was performed on the Thalassiosira weissflogi biomass to separate the water-soluble fraction from the lipid fraction [141]. The aqueous diatom extracts mainly contained $0.4 \mathrm{~g} / \mathrm{L}$ protein and $2.3 \mathrm{~g} / \mathrm{L}$ sugar eqs (chrysolaminarins). Although $81.8 \%$ of sugars in microalgal extract were consumed in $48 \mathrm{~h}$ of fermentation by T. neapolitana, $\mathrm{H}_{2}$ yields $\left(1.9 \pm 0.1 \mathrm{~mol} \mathrm{H}_{2} / \mathrm{mol}\right.$ glucose eq) (Table 3) were lower in comparison to those obtained from complex and simple sugars (around $2.7 \mathrm{~mol}$ $\mathrm{H}_{2} / \mathrm{mol}$ glucose eq.) [141]. The co-occurring decrease of lactate and acetate production suggested a minor availability of pyruvate in cultures of $T$. neapolitana on diatom extracts (Table 3) [141].

Depending on the origin of microalgal biomass, targeted strategies could be adopted to optimize the fermentation medium or to increase the carbohydrate content. 
Table 4. Fermentation of glycerol by Thermotoga spp.

\begin{tabular}{|c|c|c|c|c|c|c|c|c|c|c|c|c|}
\hline Substrate & $\begin{array}{c}\text { Pretreatment } \\
\text { Type }\end{array}$ & $\begin{array}{l}\text { Pretreatment } \\
\text { Method }\end{array}$ & $\begin{array}{c}\text { Substrate } \\
\text { Load } \\
(\mathrm{g} / \mathrm{L})\end{array}$ & Strain & $\mathrm{T}\left({ }^{\circ} \mathrm{C}\right)$ & Start pH & $\begin{array}{l}\text { Mixing } \\
\text { Speed } \\
\text { (rpm) }\end{array}$ & $\begin{array}{c}\text { Reactor } \\
\text { Volume } \\
(\mathrm{mL})\end{array}$ & $\begin{array}{c}\text { Working } \\
\text { Volume } \\
(\mathrm{mL})\end{array}$ & $\begin{array}{c}\mathrm{H}_{2} \text { Yield } \\
\text { (mol H} \mathrm{H}_{2} / \mathrm{mol} \\
\text { Sugar) }\end{array}$ & $\begin{array}{c}\text { Organic } \\
\text { Acids } \\
\text { (g/L) }\end{array}$ & Ref. \\
\hline \multirow{2}{*}{$\begin{array}{l}\text { Pure } \\
\text { glycerol }\end{array}$} & \multirow{2}{*}{-} & \multirow{2}{*}{-} & \multirow{2}{*}{5} & T.nea & \multirow{2}{*}{80} & \multirow{2}{*}{7.5} & \multirow{2}{*}{200} & \multirow{2}{*}{120} & \multirow{2}{*}{25} & 2.65 & \multirow{2}{*}{-} & \multirow{2}{*}{153} \\
\hline & & & & T.mar & & & & & & 2.75 & & \\
\hline $\begin{array}{c}\text { Biodiesel } \\
\text { waste } \\
\text { (1\% glycerol) }\end{array}$ & Mechanical & $\begin{array}{l}\text { Evaporation, } \\
\text { centrifugation }\end{array}$ & 5 & T.nea & 80 & 7.5 & - & 120 & 40 & $2.70 \pm 0.10$ & AA 1.85 & [151] \\
\hline \multirow{2}{*}{$\begin{array}{c}\text { Pure } \\
\text { glycerol }\end{array}$} & \multirow{2}{*}{-} & \multirow{2}{*}{-} & \multirow{2}{*}{2.5} & T.nea & \multirow{2}{*}{80} & \multirow{2}{*}{8} & \multirow{2}{*}{200} & \multirow{2}{*}{120} & \multirow{2}{*}{25} & 2.86 & AA 2.21 & \multirow{2}{*}[154]{} \\
\hline & & & & T.mar & & & & & & 2.84 & LA 1.74 & \\
\hline $\begin{array}{c}\text { Biodiesel } \\
\text { waste } \\
\text { (1\% glycerol) }\end{array}$ & Mechanical & $\begin{array}{l}\text { Evaporation, } \\
\text { centrifugation }\end{array}$ & 3 & T.nea & 75 & 7.5 & - & 120 & 40 & $1.3 \pm 0.06$ & - & [71] \\
\hline
\end{tabular}




\section{Molecular Basis of Sugar Catabolism and Hydrolytic Enzymes in the Family Thermotogaceae}

In recent years, several bacterial genomes of genus Thermotoga were sequenced (e.g., T. maritima, T. neapolitana, $T$. thermarum, $R Q 7$ ), revealing their versatility in utilizing various organic carbon sources [162-166]. Many members of the family Thermotogaceae possess all the genes needed for glucose catabolism by EMP, ED and OPP pathways (Supplemental Table S1), as also supported by the presence of key enzymes, such as phosphofructokinase (PFK, E.C. 2.7.1.11), 2-dehydro-3-deoxyphosphogluconate aldolase (KDPG aldolase, E.C. 4.1.2.14), and 6-phosphogluconate dehydrogenase (6PDGH, E.C. 1.1.1.44) [54]. Interestingly, these pathways showed an environmental-dependent activation mechanism in T. neapolitana, because the insufflation of $\mathrm{CO}_{2}$ instead of $\mathrm{N}_{2}$ induced the upregulation of the genes involved in ED and OPP [60]. Another peculiarity of some Thermotogales members (e.g., T.maritima) is the presence of an unconventional triosephosphate isomerase (TIM, E.C. 5.3.1.1) linked to phosphoglycerate kinase (PGK, E.C. 2.7.2.3). This anomalous association leads to a bifunctional tetrameric protein, which showed an increased stability and catalytic activity at high temperatures [167].

On the other hand, Thermotogaceae showed the presence of genes involved in monosaccharides conversion to glucose inducing an alternative flux to EMP and ED, enabling Thermotogaceae to use alternative sugar substrate sources [168-170]. Examples of these are uronate isomerase (E.C. 5.3.1.12), xylose isomerase (E.C. 5.3.1.5), mannose-1-phosphate guanylyltransferase (E.C. 2.7.7.22), phosphomannomutase (E.C. 5.4.2.8), mannose-6-phosphate isomerase (E.C. 5.3.1.8) and others. These enzymes could operate in the conversion of monosaccharides to glucose and/or glycolysis intermediates. Thermotogaceae also possess enzymes related to glucuronic and galacturonic acid metabolism, which provide an additional and specific feed into the ED pathway.

Different species of Thermotogaceae prefer different monosaccharides. Experiments performed using mixtures of glucose, fructose, arabinose, and xylose displayed similar behaviors in T. neapoliatana and T. maritima which clearly coutilized glucose and xylose instead of arabinose, while T. RQ2 quickly consumed fructose [76]. In this context, it is not surprising to find in Thermotogaceae genomes the entire regulons for monosaccharide metabolism and the $\mathrm{ABC}$ transporters for the import/export of simple and complex sugars [76]. The fine regulation of these mechanisms leads to efficient catabolism of the sugar substrates $[60,163,171]$.

Common components of fruit and vegetable waste are galactose and rhamnose $[76,163]$. As showed in Supplemental Table S1, the entire set of enzymes, related to Leloir pathway, were encoded by Thermotogaceae genomes. This pathway is specifically involved in the galactose metabolism. These enzymes include aldose 1-epimerase (E.C. 5.1.3.3), galactokinase (E.C. 2.7.1.6), galactose 1-phosphate urydil-transferase (E.C. 2.7.7.12), phosphoglucomutase (E.C. 5.4.2.2) and UDP-glucose 4-epimerase (E.C. 5.1.3.2), converting galactose to glucose 6-phosphate. The ability of Thermotogales in rhamnose metabolism was defined by the presence of rhamnose isomerase (E.C. 5.3.1.14), rhamulose kinase (E.C. 2.7.15), and rhamulose 1-phosphate aldolase, resulting in the biosynthesis of dihydroxyacetone phosphate and lactaldehyde [172]. Interestingly, this metabolic pathway is connected to both glycolysis and lactate dehydrogenase metabolism. The rhamnose metabolism pathway is totally absent in the genus Pseudothermotoga [76].

Complex sugars from different sources such as plant and algal biomass were also efficiently metabolized by Thermotogaceae $[73,95,129,130,140]$. Plant storage polysaccharides as well as starch and sucrose could be easily used as the carbon source by using enzymes such as $\alpha$-amylase, $\alpha$-glucosidase, pullulanase, and others (Supplemental Table S2). Starch is composed by $\alpha$-glucose residues mainly linked by $\alpha-1,4 / 1,6$ glycosidic bonds. The two main high molecular weight components of starch are the linear polymer amylose and the branched polymer amylopectin [173]. Thermotogaceae genomes reported the complex set of depolymerizing enzymes able to catalyze the catabolism of both linear and branched starch polymers (Supplemental Table S2). Non-reducing ends are attacked by 
enzymes such as hydrolases, $\beta$-amylase producing small oligosaccharides, while enzymes capable of hydrolyzing $\alpha-1,6$ glycosidic bonds in pullulan are defined pullulanases [173]. These enzymes ensure degradation and linearization of complex polysaccharides into a monosaccharide unit. Intriguingly, although starch is a rare carbon source in deep marine environments, especially in a hot thermal vent, extremophiles repeatedly showed starchhydrolyzing genes in their genomes, suggesting starch as an important carbon source for their metabolism [173]. Homologous starch catabolic enzymes have been identified and characterized in a number of hyperthermophilic genera, namely Pyrococcus, Thermococcus, Sulfolobus, Pyrodictium [173].

Lignocellulosic biomass represents a recalcitrant source of organic compound that requires a number of enzymatic processes to depolymerize [174]. The ability of Thermotogaceae to metabolize cellulose and hemicellulose is related to the presence of a number of cellulolytic and hemicellulolytic enzymes. Examples of these are $\beta$-glucosidase, $\alpha$ arabinofuranosidase, endo- $1,3-\beta$-xylanase, endo- $1,4-\beta$-xylanase, endo-1,4- $\beta$-mannanase etc., (Supplemental Table S2). In particular, the lignocellulosic biomass showed the presence of mannans which represent a specific form of storage and cell wall polysaccharide [175]. Thermotogaceae showed the presence of a number genes involved in mannans catabolism, namely mannonate dehydratase, D-mannonate oxidoreductase, alpha- and beta-mannosidases. Microarray analyses revealed a dramatic reorganization of Thermotogaceae transcriptomes when bacterial growth on a polysaccharide mix was compared to the growth on glucose. These data connected the ability of Thermotogaceae to ferment individual carbohydrates to the versatile set of $A B C$ transporters [76]. The hemicellulolytic enzymes from $T$. neapolitana were tested to solubilize lignocellulosic products from barley straw and corn bran, which improved the yield of fermentable sugars up to $65 \%$ compared to traditional systems [86]. T. maritima cellulase has also been overexpressed in tobacco and Arabidopsis chloroplasts to maximize the production of this cellulolytic enzyme [175]. The biomass of brown algae and diatoms, particularly polysaccharides such as sucrose and laminarin, were easily fermented by Thermotogaceae [73]. It is worth pointing out that genes coding for laminarinase, endoglucanase $(\beta 1 \rightarrow 3$ and $\beta 1 \rightarrow 4)$, glucosidase (alfa ad beta), and similar enzymes are frequently noticed in Thermotogaceae genomes. Interesting differences were reported between Thermotogae and Pseudothermotogae genomes, regarding polysaccharide catabolic enzymes (Supplemental Table S2). The ability of Thermotogales to use microalgal biomass as an organic source could be confirmed by the presence of genes related to lipid catabolism, such as lipase (CTN_RS06200), glycoside hydrolase 4 related to glycolipids and sphingolipids (CTN_RS09115), and alpha-galactosidase related to glycolipids (CTN_RS06915).

\section{Conclusions and Future Perspective}

Biodegradable organic waste is a promising carbon source to be exploited in a more circular and sustainable worldwide economy. Their abundance and heterogeneity in terms of compositional and structural features, associated to their origins, allow them to be widely used for biogas production, mainly biohydrogen, biofuels such as bioethanol, and valueadded products (acetic acid, lactic acid, etc.). In the last few years, microbial anaerobic fermentation has become a promising way to obtain high production yields of bioenenergy and green chemicals, and hyperthermophilic bacteria capable of metabolizing complex sugars via a dark fermentation process represent the new frontier of biotechnological development. The hyperthermophilic family Thermotogaceae, including the Thermotoga and Pseudothermotoga genera, are recognized for their ability to produce $\mathrm{H}_{2}$ from many complex substrates.

This review demonstrates that Thermotoga and Pseudothermotoga spp. have an enormous biotechnological potential in fermenting organic waste originated from food, glycerol, lignocellulosic, and microalgal biomasses. In particular, T. maritima, T. neapolitana and P. elfii have been recognized as the best candidates in this scientific landscape. Their ability to degrade complex substrates is due to their unique metabolic and genomic features. 
Many studies have been performed to find the best employment strategies and to identify putative transporters, enzymes, pathways, limiting factors, and pretreatment methods. The extreme growth temperatures of these bacteria not only reduce contamination by environmental bacteria but also make complex substrates easier to solubilize, avoiding, in some cases, the pretreatment step, which helps to preserve major components of the substrates and increase their availability.

Several studies were carried out to investigate the effect of different mechanical, thermal, chemical, and biological pretreatment methods on biodegradable organic waste to develop more sustainable processes. They can also include the combined use of different substrates to balance nutritional requests. The synergistic activities of two strains may also be exploited to metabolize complex substrates. For example, C. saccharolyticus can provide thermostable cellulolytic and xylanolytic enzymes, allowing the growth on complex lignocellulosic carbon sources and the co-metabolization of a wide range of monosaccharides including both pentose and hexose sugars. On the other hand, T. maritima and T. neapolitana can grow either on various C5 and C6 sugars, starch, glycogen, or complex organic substrates with hydrogen yields close to the maximum theoretical values. Co-cultivating C. saccharolyticus and Thermotoga can maximize the utilization of cellulosic substrates while ensuring optimal $\mathrm{H}_{2}$ yield.

The collective knowledge we gained so far will allow us to experiment with several waste fermentation strategies with members of the Thermotogaceae family. The existence of unprecedented pathways, like the capnophilic lactic fermentation pathway discovered in T. neapolitana, which pairs $\mathrm{CO}_{2}$ and acetate to produce lactic acid at high yields and at the same time detoxifies the environment from $\mathrm{CO}_{2}$, further illustrates the great potentials of the Thermotoga and Pseudothermotoga genera in establishing a sustainable economy based on waste elimination and exploitation.

Supplementary Materials: The following are available online at https:/ /www.mdpi.com/article/10 .3390/resources10040034/s1, Table S1: List of Thermotogales genes related to glycolytic pathways.Data have been exported from Ensembl Bacteria database; Table S2: List of Thermotogales genes related to organic catabolism. Data have been exported from Ensembl Bacteria database.

Author Contributions: Conceptualization, G.d. and N.E.; writing—original draft preparation, N.E., M.L., M.V., bioinformatic analysis, S.L.; writing-review and editing, all authors; editing and revision, Z.X.; supervision, G.d.; funding acquisition and project administration, A.F. and G.d. All authors have read and agreed to the published version of the manuscript.

Funding: This research was funded by BioRECO2VER Project, through the European Union's Horizon 2020 Research and Innovation Programme under Grant Agreement No. 760431.

Institutional Review Board Statement: Not applicable.

Informed Consent Statement: Not applicable.

Data Availability Statement: Not applicable.

Acknowledgments: The authors would like to thank Lucio Caso (CNR-ICB) for the technical support in preparing the manuscript.

Conflicts of Interest: The authors declare no conflict of interest. The funding agencies gave their permissions to the publication of manuscript.

\section{References}

1. Perea-Moreno, M.A.; Samerón-Manzano, E.; Perea-Moreno, A.J. Biomass as renewable energy: Worldwide research trends. Sustainability 2019, 11, 863. [CrossRef]

2. Wainaina, S.; Awasthi, M.K.; Sarsaiya, S.; Chen, H.; Singh, E.; Kumar, A.; Ravindran, B.; Awasthi, S.K.; Liu, T.; Duan, Y.; et al. Resource recovery and circular economy from organic solid waste using aerobic and anaerobic digestion technologies. Bioresour. Technol. 2020, 301, 122778. [CrossRef] [PubMed]

3. Muthu, S. Recycling of Solid Waste for Biofuels and Bio-Chemicals; Obulisamy, P., Heimann, K., Muthu, S., Eds.; Springer: Berlin/Heidelberg, Germany, 2016. 
4. European Commission Updated Bioeconomy Strategy. Available online: https://ec.europa.eu/knowledge4policy/publication/ updated-bioeconomy-strategy-2018_en (accessed on 12 April 2021).

5. Bouallagui, H.; Touhami, Y.; Ben Cheikh, R.; Hamdi, M. Bioreactor performance in anaerobic digestion of fruit and vegetable wastes. Process. Biochem. 2005, 40, 989-995. [CrossRef]

6. Kapdan, I.K.; Kargi, F. Bio-hydrogen production from waste materials. Enzym. Microb. Technol. 2006, 38, 569-582. [CrossRef]

7. Lin, C.Y.; Lay, C.H.; Sen, B.; Chu, C.Y.; Kumar, G.; Chen, C.C.; Chang, J.S. Fermentative hydrogen production from wastewaters: A review and prognosis. Int. J. Hydrogen Energy 2012, 37, 15632-15642. [CrossRef]

8. Nasir, I.M.; Ghazi, T.I.M.; Omar, R. Production of biogas from solid organic wastes through anaerobic digestion: A review. Appl. Microbiol. Biotechnol. 2012, 95, 321-329. [CrossRef]

9. Atelge, M.R.; Krisa, D.; Kumar, G.; Eskicioglu, C.; Nguyen, D.D.; Chang, S.W.; Atabani, A.E.; Al-Muhtaseb, A.H.; Unalan, S. Biogas Production from Organic Waste: Recent Progress and Perspectives. Waste Biomass Valorization 2020, 11, 1019-1040. [CrossRef]

10. Lee, S.Y.; Sankaran, R.; Chew, K.W.; Tan, C.H.; Krishnamoorthy, R.; Chu, D.-T.; Show, P.-L. Waste to bioenergy: A review on the recent conversion technologies. Bmc Energy 2019, 1, 1-22. [CrossRef]

11. Kumar, P.; Gnansounou, E.; Raman, J.K.; Baskar, G. Refining Biomass Residues for Sustainable Energy and Bioproducts; Elsevier: Amsterdam, The Netherlands, 2019.

12. Dung, T.N.B.; Sen, B.; Chen, C.C.; Kumar, G.; Lin, C.Y. Food waste to bioenergy via anaerobic processes. Energy Procedia 2014, 61, 307-312. [CrossRef]

13. Pham, T.P.T.; Kaushik, R.; Parshetti, G.K.; Mahmood, R.; Balasubramanian, R. Food waste-to-energy conversion technologies: Current status and future directions. Waste Manag. 2015, 38, 399-408. [CrossRef]

14. Alibardi, L.; Cossu, R. Effects of carbohydrate, protein and lipid content of organic waste on hydrogen production and fermentation products. Waste Manag. 2016, 47, 69-77. [CrossRef]

15. Boodhun, B.S.F.; Mudhoo, A.; Kumar, G.; Kim, S.H.; Lin, C.Y. Research perspectives on constraints, prospects and opportunities in biohydrogen production. Int. J. Hydrogen Energy 2017, 42, 27471-27481. [CrossRef]

16. Staffell, I.; Scamman, D.; Velazquez Abad, A.; Balcombe, P.; Dodds, P.E.; Ekins, P.; Shah, N.; Ward, K.R. The role of hydrogen and fuel cells in the global energy system. Energy Environ. Sci. 2019, 12, 463-491. [CrossRef]

17. Chong, M.L.; Sabaratnam, V.; Shirai, Y.; Hassan, M.A. Biohydrogen production from biomass and industrial wastes by dark fermentation. Int. J. Hydrogen Energy 2009, 34, 3277-3287. [CrossRef]

18. Pradhan, N.; Dipasquale, L.; D'Ippolito, G.; Panico, A.; Lens, P.N.L.; Esposito, G.; Fontana, A. Hydrogen production by the thermophilic bacterium Thermotoga neapolitana. Int. J. Mol. Sci. 2015, 16, 12578-12600. [CrossRef] [PubMed]

19. Dincer, I.; Acar, C. Smart energy solutions with hydrogen options. Int. J. Hydrogen Energy 2018, 43, 8579-8599. [CrossRef]

20. Ntaikou, I.; Antonopoulou, G.; Lyberatos, G. Biohydrogen production from biomass and wastes via dark fermentation: A review. Waste Biomass Valorization 2010, 1, 21-39. [CrossRef]

21. Khanna, N.; Das, D. Biohydrogen production by dark fermentation. Wiley Interdiscip. Rev. Energy Environ. 2012, 2, 401-421. [CrossRef]

22. Raj, S.M.; Talluri, S.; Christopher, L.P. Thermophilic Hydrogen Production from Renewable Resources: Current Status and Future Perspectives. Bioenergy Res. 2012, 5, 515-531. [CrossRef]

23. Pawar, S.S.; Van Niel, E.W.J. Thermophilic biohydrogen production: How far are we? Appl. Microbiol. Biotechnol. 2013, 97, 7999-8009. [CrossRef]

24. Kothari, R.; Kumar, V.; Pathak, V.V.; Ahmad, S.; Aoyi, O.; Tyagi, V.V. A critical review on factors influencing fermentative hydrogen production. Front. Biosci. Landmark 2017, 22, 1195-1220. [CrossRef]

25. Schönheit, P.; Schäfer, T. Metabolism of hyperthermophiles. World J. Microbiol. Biotechnol. 1995, 11, 26-57. [CrossRef] [PubMed]

26. Van Ooteghem, S.A.; Beer, S.K.; Yue, P.C. Hydrogen production by the thermophilic bacterium Thermotoga neapolitana. Appl. Biochem. Biotechnol. Enzym. Eng. Biotechnol. 2002, 98-100, 177-189. [CrossRef]

27. Shao, W.; Wang, Q.; Rupani, P.F.; Krishnan, S.; Ahmad, F.; Rezania, S.; Rashid, M.A.; Sha, C.; Din, M.F. Biohydrogen production via thermophilic fermentation: A prospective application of Thermotoga species. Energy 2020, 197. [CrossRef]

28. Huber, R.; Hannig, M. Thermotogales. Prokaryotes 2006, 899-922. [CrossRef]

29. Turner, P.; Mamo, G.; Karlsson, E.N. Potential and utilization of thermophiles and thermostable enzymes in biorefining. Microb. Cell Fact. 2007, 6. [CrossRef]

30. Blumer-Schuette, S.E.; Kataeva, I.; Westpheling, J.; Adams, M.W.; Kelly, R.M. Extremely thermophilic microorganisms for biomass conversion: Status and prospects. Curr. Opin. Biotechnol. 2008, 19, 210-217. [CrossRef]

31. Arora, R.; Behera, S.; Kumar, S. Bioprospecting thermophilic/thermotolerant microbes for production of lignocellulosic ethanol: A future perspective. Renew. Sustain. Energy Rev. 2015, 51, 699-717. [CrossRef]

32. Pradhan, N.; Dipasquale, L.; d'Ippolito, G.; Fontana, A.; Panico, A.; Pirozzi, F.; Lens, P.N.L.; Esposito, G. Model development and experimental validation of capnophilic lactic fermentation and hydrogen synthesis by Thermotoga neapolitana. Water Res. 2016, 99, 225-234. [CrossRef]

33. Pradhan, N.; Dipasquale, L.; D’Ippolito, G.; Fontana, A.; Panico, A.; Lens, P.N.L.; Pirozzi, F.; Esposito, G. Kinetic modeling of fermentative hydrogen production by Neapolitana. Int. J. Hydrogen Energy 2016, 41, 4931-4940. [CrossRef] 
34. Dipasquale, L.; Pradhan, N.; Ippolito, G.; Fontana, A. Potential of Hydrogen Fermentative Pathways in Marine Thermophilic Bacteria: Dark Fermentation and Capnophilic Lactic Fermentation. In Thermotoga and Pseudothermotoga Species; Elsevier: Cham, Switzerland, 2018; pp. 217-235.

35. Okonkwo, O.; Lakaniemi, A.M.; Santala, V.; Karp, M.; Mangayil, R. Quantitative real-time PCR monitoring dynamics of Thermotoga neapolitana in synthetic co-culture for biohydrogen production. Int. J. Hydrogen Energy 2018, 43, $3133-3141$. [CrossRef]

36. Eriksen, N.T.; Riis, M.L.; Holm, N.K.; Iversen, N. H2 synthesis from pentoses and biomass in Thermotoga spp. Biotechnol. Lett. 2011, 33, 293-300. [CrossRef]

37. Cappelletti, M.; Davide, Z.; Anne Postec, B.O. Members of the Order Thermotogales: From Microbiology to Hydrogen Production. Microb. Bioenergy Hydrog. Prod. Adv. Photosynth. Respir. 2014, 38, 321-347. [CrossRef]

38. Cappelletti, M.; Bucchi, G.; De Sousa Mendes, J.; Alberini, A.; Fedi, S.; Bertin, L.; Frascari, D. Biohydrogen production from glucose, molasses and cheese whey by suspended and attached cells of four hyperthermophilic Thermotoga strains. J. Chem. Technol. Biotechnol. 2012, 87, 1291-1301. [CrossRef]

39. Saidi, R.; Liebgott, P.P.; Gannoun, H.; Ben Gaida, L.; Miladi, B.; Hamdi, M.; Bouallagui, H.; Auria, R. Biohydrogen production from hyperthermophilic anaerobic digestion of fruit and vegetable wastes in seawater: Simplification of the culture medium of Thermotoga maritima. Waste Manag. 2018, 71, 474-484. [CrossRef]

40. Saidi, R.; Liebgott, P.P.; Hamdi, M.; Auria, R.; Bouallagui, H. Enhancement of fermentative hydrogen production by Thermotoga maritima through hyperthermophilic anaerobic co-digestion of fruit-vegetable and fish wastes. Int. J. Hydrogen Energy 2018, 43, 23168-23177. [CrossRef]

41. Saidi, R.; Hamdi, M.; Bouallagui, H. Hyperthermophilic hydrogen production in a simplified reaction medium containing onion wastes as a source of carbon and sulfur. Environ. Sci. Pollut. Res. 2020. [CrossRef]

42. Ravindran, R.; Jaiswal, A.K. A comprehensive review on pre-treatment strategy for lignocellulosic food industry waste: Challenges and opportunities. Bioresour. Technol. 2016, 199, 92-102. [CrossRef]

43. Galbe, M.; Wallberg, O. Pretreatment for biorefineries: A review of common methods for efficient utilisation of lignocellulosic materials. Biotechnol. Biofuels 2019, 12, 1-26. [CrossRef] [PubMed]

44. Sayara, T.; Sánchez, A. A review on anaerobic digestion of lignocellulosic wastes: Pretreatments and operational conditions. Appl. Sci. 2019, 9, 4655. [CrossRef]

45. Conners, S.B.; Montero, C.I.; Comfort, D.A.; Shockley, K.R.; Johnson, M.R.; Chhabra, S.R.; Kelly, R.M. An Expression-Driven Approach to the Prediction of Carbohydrate Transport and Utilization Regulons in the Hyperthermophilic Bacterium Thermotoga maritima t. J. Bacteriol. 2005, 187, 7267-7282. [CrossRef]

46. Conners, S.B.; Mongodin, E.F.; Johnson, M.R.; Montero, C.I.; Nelson, K.E.; Kelly, R.M. Microbial biochemistry, physiology, and biotechnology of hyperthermophilic Thermotoga species. Fems Microbiol. Rev. 2006, 30, 872-905. [CrossRef]

47. Chhabra, S.R.; Shockley, K.R.; Conners, S.B.; Scott, K.L.; Wolfinger, R.D.; Kelly, R.M. Carbohydrate-induced differential gene expression patterns in the hyperthermophilic bacterium Thermotoga maritima. J. Biol. Chem. 2003, 278, 7540-7552. [CrossRef] [PubMed]

48. Bhandari, V.; Gupta, R.S. Molecular signatures for the phylum (class) Thermotogae and a proposal for its division into three orders (Thermotogales, Kosmotogales ord. Nov. and Petrotogales ord. Nov.) containing four families (Thermotogaceae, Fervidobacteriaceae fam. Nov., Kosmotoga. Antonie Van Leeuwenhoek Int. J. Gen. Mol. Microbiol. 2014, 105, 143-168. [CrossRef] [PubMed]

49. Belahbib, H.; Summers, Z.M.; Fardeau, M.L.; Joseph, M.; Tamburini, C.; Dolla, A.; Ollivier, B.; Armougom, F. Towards a congruent reclassification and nomenclature of the thermophilic species of the genus Pseudothermotoga within the order Thermotogales. Syst. Appl. Microbiol. 2018, 41, 555-563. [CrossRef] [PubMed]

50. Reysenbach, A.-L. Phylum BII. Thermotogae phy.nov. In Bergey's Manual of Systematic Bacteriology; Springer: New York, NY, USA, 2002.

51. Thauer, R.K.; Jungermann, K.; Decker, K. Energy Conservation in Chemotrophic Anaerobic Bacteria. Bacteriol. Rev. 1977, $41,809$. [CrossRef]

52. Selig, M.; Xavier, K.B.; Santos, H.; Schönheit, P. Comparative analysis of Embden-Meyerhof and Entner-Doudoroff glycolytic pathways in hyperthermophilic archaea and the bacterium Thermotoga. Arch. Microbiol. 1997, 167, 217-232. [CrossRef]

53. Romano, A.H.; Conway, T. Evolution of carbohydrate metabolic pathways. Res. Microbiol. 1996, 147, 448-455. [CrossRef]

54. Flamholz, A.; Noor, E.; Bar-Even, A.; Liebermeister, W.; Milo, R. Glycolytic strategy as a tradeoff between energy yield and protein cost. Proc. Natl. Acad. Sci. USA 2013, 110, 10039-10044. [CrossRef]

55. Dipasquale, L.; D'Ippolito, G.; Fontana, A. Capnophilic lactic fermentation and hydrogen synthesis by Thermotoga neapolitana: An unexpected deviation from the dark fermentation model. Int. J. Hydrogen Energy 2014, 39, 4857-4862. [CrossRef]

56. d'Ippolito, G.; Dipasquale, L.; Fontana, A. Recycling of Carbon Dioxide and Acetate as Lactic Acid by the Hydrogen-Producing Bacterium Thermotoga neapolitana. ChemSusChem 2014, 7, 2678-2683. [CrossRef]

57. Dipasquale, L.; Adessi, A.; d'Ippolito, G.; Rossi, F.; Fontana, A.; De Philippis, R. Introducing capnophilic lactic fermentation in a combined dark-photo fermentation process: A route to unparalleled H2 yields. Appl. Microbiol. Biotechnol. 2015, 99, 1001-1010. [CrossRef]

58. d'Ippolito, G.; Dipasquale, L.; Vella, F.M.; Romano, I.; Gambacorta, A.; Cutignano, A.; Fontana, A. Hydrogen metabolism in the extreme thermophile Thermotoga neapolitana. Int. J. Hydrogen Energy 2010, 35, 2290-2295. [CrossRef] 
59. Nuzzo, G.; Landi, S.; Esercizio, N.; Manzo, E.; Fontana, A.; D’Ippolito, G. Capnophilic lactic fermentation from Thermotoga neapolitana: A resourceful pathway to obtain almost enantiopure L-lactic acid. Fermentation 2019, 5, 34. [CrossRef]

60. d'Ippolito, G.; Landi, S.; Esercizio, N.; Lanzilli, M.; Vastano, M.; Dipasquale, L.; Pradhan, N.; Fontana, A. CO2-Induced Transcriptional Reorganization: Molecular Basis of Capnophillic Lactic Fermentation in Thermotoga neapolitana. Front. Microbiol. 2020, 11. [CrossRef] [PubMed]

61. Xu, H.; Han, D.; Xu, Z. Expression of Heterologous Cellulases in Thermotoga sp. Strain RQ2. BioMed Res. Int. 2014, $2015,304523$. [CrossRef]

62. Balk, M.; Weijma, J.; Stams, A.J.M. Thermotoga lettingae sp. nov., a novel thermophilic, methanol-degrading bacterium isolated from a thermophilic anaerobic reactor. Int. J. Syst. Evol. Microbiol. 2002, 52, 1361-1368. [CrossRef] [PubMed]

63. Huber, R.; Langworthy, T.A.; König, H.; Thomm, M.; Woese, C.R.; Sleytr, U.B.; Stetter, K.O. Thermotoga maritima sp. nov. represents a new genus of unique extremely thermophilic eubacteria growing up to $90{ }^{\circ} \mathrm{C}$. Arch. Microbiol. 1986, 144, 324-333. [CrossRef]

64. Jannasch, H.W.; Huber, R.; Belkin, S.; Stetter, K.O. Thermotoga neapolitana sp. nov. of the extremely thermophilic, eubacterial genus Thermotoga. Arch. Microbiol. 1988, 150, 103-104. [CrossRef]

65. Windberger, E.; Huber, R.; Trincone, A.; Fricke, H.; Stetter, K.O. Thermotoga thermarum sp. nov. and Thermotoga neapolitana occurring in African continental solfataric springs. Arch. Microbiol. 1989, 151, 506-512. [CrossRef]

66. Jeanthon, C.; Reysenbach, A.L.; L'Haridon, S.; Gambacorta, A.; Pace, N.R.; Glénat, P.; Prieur, D. Thermotoga subterranea sp. nov., a new thermophilic bacterium isolated from a continental oil reservoir. Arch. Microbiol. 1995, 164, 91-97. [CrossRef]

67. Ravot, G.; Magot, M.; Fardeau, M.L.; Patel, B.K.C.; Prensier, G.; Egan, A.; Garcia, J.L.; Ollivier, B. Thermotoga elfii sp. nov., a novel thermophilic bacterium from an African oil-producing well. Int. J. Syst. Bacteriol. 1995, 45, 308-314. [CrossRef]

68. Fardeau, M.-L.; Ollivier, I.; Patel, B.; Magot, M.; Thomas, P.; Rimbault, A.; Rocchiccioli, F.; Garcia', J. Thermotoga hypogea sp. nov., a Xylanolytic, Thermophilic Bacterium from an Oil-Producing Well. Int. J. Syst. Evol. Microbiol. 1997, 147, 51-56. [CrossRef] [PubMed]

69. Takahata, Y.; Nishijima, M.; Hoaki, T.; Maruyama, T. Thermotoga petrophila sp. nov. and Thermotoga naphthophila sp. nov., two hyperthermophilic bacteria from the Kubiki oil reservoir in Niigata, Japan. Int. J. Syst. Evol. Microbiol. 2001, 51, 1901-1909. [CrossRef] [PubMed]

70. Nguyen, T.A.D.; Han, S.J.; Kim, J.P.; Kim, M.S.; Sim, S.J. Hydrogen production of the hyperthermophilic eubacterium, Thermotoga neapolitana under N2 sparging condition. Bioresour. Technol. 2010, 101, S38-S41. [CrossRef] [PubMed]

71. Ngo, T.A.; Sim, S.J. Dark fermentation of hydrogen from waste glycerol using hyperthermophilic eubacterium Thermotoga neapolitana. Environ. Prog. Sustain. Energy 2012, 31, 466-473. [CrossRef]

72. Ngo, T.A.; Kim, M.S.; Sim, S.J. Thermophilic hydrogen fermentation using Thermotoga neapolitana DSM 4359 by fed-batch culture. Int. J. Hydrogen Energy 2011, 36, 14014-14023. [CrossRef]

73. Pradhan, N.; d’Ippolito, G.; Dipasquale, L.; Esposito, G.; Panico, A.; Lens, P.N.L.; Fontana, A. Simultaneous synthesis of lactic acid and hydrogen from sugars via capnophilic lactic fermentation by Thermotoga neapolitana cf capnolactica. Biomass Bioenergy 2019, 125, 17-22. [CrossRef]

74. Woodward, J.; Heyer, N.I.; Getty, J.P.; Neill, H.M.O.; Pinkhassik, E.; Evans, B.R. Efficient Hydrogen Production Using Enzymes of the Pentose Phosphate Pathway. In Proceedings of the 2002 U.S. DOE Hydrogen Program Review, Golden, CO, USA, 6-10 May 2002; pp. 1-12.

75. De Vrije, T.; Budde, M.A.W.; Lips, S.J.; Bakker, R.R.; Mars, A.E.; Claassen, P.A.M. Hydrogen production from carrot pulp by the extreme thermophiles Caldicellulosiruptor saccharolyticus and Thermotoga neapolitana. Int. J. Hydrogen Energy 2010, 35, 13206-13213. [CrossRef]

76. Frock, A.D.; Gray, S.R.; Kelly, R.M. Hyperthermophilic Thermotoga species differ with respect to specific carbohydrate transporters and glycoside hydrolases. Appl. Environ. Microbiol. 2012. [CrossRef]

77. Abreu, A.A.; Tavares, F.; Alves, M.M.; Pereira, M.A. Boosting dark fermentation with co-cultures of extreme thermophiles for biohythane production from garden waste. Bioresour. Technol. 2016, 219, 132-138. [CrossRef]

78. Yu, X.; Drapcho, C.M.; Drapcho, C.M. Hydrogen Production by the Hyperthermophilic Bacterium Thermotoga neapolitana using Agricultural-Based Carbon and Nitrogen Sources. Biol. Eng. Trans. 2011, 4, 101-112. [CrossRef]

79. Vargas, M.; Noll, K.M. Catabolite repression in the hyperthermophilic bacterium Thermotoga neapolitana is independent of cAMP. Microbiology 1996, 142, 139-144. [CrossRef] [PubMed]

80. Nguyen, T.N.; Ejaz, A.D.; Brancieri, M.A.; Mikula, A.M.; Nelson, K.E.; Gill, S.R.; Noll, K.M. Whole-genome expression profiling of Thermotoga maritima in response to growth on sugars in a chemostat. J. Bacteriol. 2004, 186, 4824-4828. [CrossRef] [PubMed]

81. Nguyen, T.A.D.; Han, S.J.; Kim, J.P.; Kim, M.S.; Oh, Y.K.; Sim, S.J. Hydrogen production by the hyperthermophilic eubacterium, Thermotoga neapolitana, using cellulose pretreated by ionic liquid. Int. J. Hydrogen Energy 2008, 33, 5161-5168. [CrossRef]

82. Nguyen, T.A.D.; Pyo Kim, J.; Sun Kim, M.; Kwan Oh, Y.; Sim, S.J. Optimization of hydrogen production by hyperthermophilic eubacteria, Thermotoga maritima and Thermotoga neapolitana in batch fermentation. Int. J. Hydrogen Energy 2008, 33, 1483-1488. [CrossRef]

83. Ngo, T.A.; Nguyen, T.H.; Bui, H.T.V. Thermophilic fermentative hydrogen production from xylose by Thermotoga neapolitana DSM 4359. Renew. Energy 2012, 37, 174-179. [CrossRef]

84. Singh, R.; White, D.; Demirel, Y.; Kelly, R.; Noll, K.; Blum, P. Uncoupling fermentative synthesis of molecular hydrogen from biomass formation in Thermotoga maritima. Appl. Environ. Microbiol. 2018, 84. [CrossRef] 
85. Van Niel, E.W.J.; Budde, M.A.W.; De Haas, G.; Van der Wal, F.J.; Claassen, P.A.M.; Stams, A.J.M. Distinctive properties of high hydrogen producing extreme thermophiles, Caldicellulosiruptor saccharolyticus and Thermotoga elfii. Int. J. Hydrogen Energy 2002, 27, 1391-1398. [CrossRef]

86. Benedetti, M.; Vecchi, V.; Betterle, N.; Natali, A.; Bassi, R.; Dall'Osto, L. Design of a highly thermostable hemicellulose-degrading blend from Thermotoga neapolitana for the treatment of lignocellulosic biomass. J. Biotechnol. 2019, 296, 42-52. [CrossRef]

87. Paritosh, K.; Kushwaha, S.K.; Yadav, M.; Pareek, N.; Chawade, A.; Vivekanand, V. Food Waste to Energy: An Overview of Sustainable Approaches for Food Waste Management and Nutrient Recycling. Available online: https://www.hindawi.com/ journals/bmri/2017/2370927/ (accessed on 15 April 2020).

88. Yun, Y.; Lee, M.; Im, S.; Marone, A.; Trably, E.; Shin, S.; Kim, M.; Cho, S.; Kim, D. Bioresource Technology Biohydrogen production from food waste: Current status, limitations, and future perspectives. Bioresour. Technol. 2018, 248, 79-87. [CrossRef]

89. Garcia-Peña, E.I.; Parameswaran, P.; Kang, D.W.; Canul-Chan, M.; Krajmalnik-Brown, R. Anaerobic digestion and co-digestion processes of vegetable and fruit residues: Process and microbial ecology. Bioresour. Technol. 2011, 102, 9447-9455. [CrossRef]

90. Bouallagui, H.; Lahdheb, H.; Ben Romdan, E.; Rachdi, B.; Hamdi, M. Improvement of fruit and vegetable waste anaerobic digestion performance and stability with co-substrates addition. J. Environ. Manag. 2009, 90, 1844-1849. [CrossRef]

91. Thanikal, J. Anaerobic Co-digestion of fruit and vegetable waste: Bio- reactor performance. World. J. Exp. Biosci. $2015,3,1-17$.

92. Bao, B.; Chang, K.C. Carrot Pulp Chemical Composition, Color, and Water-holding Capacity as Affected by Blanching. J. Food Sci. 1994, 59, 1159-1161. [CrossRef]

93. Claassen, P.A.; Budde, M.A.; van Nooren, G.E.; Hoekema, S.; Hazewinkel, J.H.O.; van Gorensestijn, J.W.; de Vrije, G.J. Biological hydrogen production from agro-food-by-products. In Proceedings of the Total Food: Exploiting Co-Products, Norwich, UK, 25-28 April 2004.

94. Djomo, S.N.; Humbert, S. Dagnija Blumberga Life cycle assessment of hydrogen produced from potato steam peels. Int. J. Hydrogen Energy 2008, 33, 3067-3072. [CrossRef]

95. Mars, A.E.; Veuskens, T.; Budde, M.A.W.; Van Doeveren, P.F.N.M.; Lips, S.J.; Bakker, R.R.; De Vrije, T.; Claassen, P.A.M. Biohydrogen production from untreated and hydrolyzed potato steam peels by the extreme thermophiles Caldicellulosiruptor saccharolyticus and Thermotoga neapolitana. Int. J. Hydrogen Energy 2010, 35, 7730-7737. [CrossRef]

96. Benítez, V.; Mollá, E.; Martín-Cabrejas, M.A.; Aguilera, Y.; López-Andréu, F.J.; Cools, K.; Terry, L.A.; Esteban, R.M. Characterization of Industrial Onion Wastes (Allium cepa L.): Dietary Fibre and Bioactive Compounds. Plant. Foods Hum. Nutr. 2011, 66, 48-57. [CrossRef] [PubMed]

97. Romano, R.T.; Zhang, R. Anaerobic digestion of onion residuals using a mesophilic Anaerobic Phased Solids Digester. Biomass Bioenergy 2011, 35, 4174-4179. [CrossRef]

98. Milquez-Sanabria, H.; Blanco-Cocom, L.; Alzate-Gaviria, L. A fast linear predictive adaptive model of packed bed coupled with UASB reactor treating onion waste to produce biofuel. Microb. Cell Fact. 2016, 15, 1-10. [CrossRef] [PubMed]

99. Sharma, K.; Mahato, N.; Nile, S.H.; Lee, E.T.; Lee, Y.R. Economical and environmentally-friendly approaches for usage of onion (: Allium cepa L.) waste. Food Funct. 2016, 7, 3354-3369. [CrossRef] [PubMed]

100. Kadam, K.L.; Forrest, L.H.; Jacobson, W.A. Rice straw as a lignocellulosic resource: Collection, processing, transportation, and environmental aspects. Biomass Bioenergy 2000, 18, 369-389. [CrossRef]

101. Kim, S.; Dale, B.E. Global potential bioethanol production from wasted crops and crop residues. Biomass Bioenergy 2004, 26, 361-375. [CrossRef]

102. Nguyen, T.A.D.; Kim, K.R.; Kim, M.S.; Sim, S.J. Thermophilic hydrogen fermentation from Korean rice straw by Thermotoga neapolitana. Int. J. Hydrogen Energy 2010, 35, 13392-13398. [CrossRef]

103. Chang, A.C.C.; Tu, Y.H.; Huang, M.H.; Lay, C.H.; Lin, C.Y. Hydrogen production by the anaerobic fermentation from acid hydrolyzed rice straw hydrolysate. Int. J. Hydrogen Energy 2011, 36, 14280-14288. [CrossRef]

104. He, L.; Huang, H.; Lei, Z.; Liu, C.; Zhang, Z. Enhanced hydrogen production from anaerobic fermentation of rice straw pretreated by hydrothermal technology. Bioresour. Technol. 2014, 171, 145-151. [CrossRef]

105. Wang, D.; Ai, P.; Yu, L.; Tan, Z.; Zhang, Y. Comparing the hydrolysis and biogas production performance of alkali and acid pretreatments of rice straw using two-stage anaerobic fermentation. Biosyst. Eng. 2015, 132, 47-55. [CrossRef]

106. Kim, T.H.; Lee, Y.Y. Pretreatment of corn stover by soaking in aqueous ammonia. Appl. Biochem. Biotechnol. Part A Enzym. Eng. Biotechnol. 2005, 124, 1119-1131. [CrossRef]

107. Wyman, C.E.; Dale, B.E.; Elander, R.T.; Holtzapple, M.; Ladisch, M.R.; Lee, Y.Y. Coordinated development of leading biomass pretreatment technologies. Bioresour. Technol. 2005, 96, 1959-1966. [CrossRef]

108. Ren, N.; Li, J.; Li, B.; Wang, Y.; Liu, S. Biohydrogen production from molasses by anaerobic fermentation with a pilot-scale bioreactor system. Int. J. Hydrogen Energy 2006, 31, 2147-2157. [CrossRef]

109. Li, J.; Li, B.; Zhu, G.; Ren, N.; Bo, L.; He, J. Hydrogen production from diluted molasses by anaerobic hydrogen producing bacteria in an anaerobic baffled reactor (ABR). Int. J. Hydrogen Energy 2007, 32, 3274-3283. [CrossRef]

110. Aceves-Lara, C.A.; Latrille, E.; Bernet, N.; Buffière, P.; Steyer, J.P. A pseudo-stoichiometric dynamic model of anaerobic hydrogen production from molasses. Water Res. 2008, 42, 2539-2550. [CrossRef] [PubMed]

111. Wang, X.; Jin, B. Process optimization of biological hydrogen production from molasses by a newly isolated Clostridium butyricum W5. J. Biosci. Bioeng. 2009, 107, 138-144. [CrossRef] [PubMed] 
112. Scoma, A.; Coma, M.; Kerckhof, F.M.; Boon, N.; Rabaey, K. Efficient molasses fermentation under high salinity by inocula of marine and terrestrial origin. Biotechnol. Biofuels 2017, 10, 1-17. [CrossRef] [PubMed]

113. Frascari, D.; Cappelletti, M.; Mendes, J.D.S.; Alberini, A.; Scimonelli, F.; Manfreda, C.; Longanesi, L.; Zannoni, D.; Pinelli, D.; Fedi, S. A kinetic study of biohydrogen production from glucose, molasses and cheese whey by suspended and attached cells of Thermotoga neapolitana. Bioresour. Technol. 2013, 147, 553-561. [CrossRef]

114. Carvalho, F.; Prazeres, A.R.; Rivas, J. Cheese whey wastewater: Characterization and treatment. Sci. Total Environ. 2013, 445-446, 385-396. [CrossRef]

115. Lopes, A.C.A.; Eda, S.H.; Andrade, R.P.; Amorim, J.C.; Duarte, W.F. New Alcoholic Fermented Beverages-Potentials and Challenges. Fermented Beverages 2019, 577-603. [CrossRef]

116. Zotta, T.; Solieri, L.; Iacumin, L.; Picozzi, C.; Gullo, M. Valorization of cheese whey using microbial fermentations. Appl. Microbiol. Biotechnol. 2020, 104, 2749-2764. [CrossRef]

117. Ren, N.; Wang, A.; Cao, G.; Xu, J.; Gao, L. Bioconversion of lignocellulosic biomass to hydrogen: Potential and challenges. Biotechnol. Adv. 2009, 27, 1051-1060. [CrossRef]

118. Alvira, P.; Tomás-Pejó, E.; Ballesteros, M.; Negro, M.J. Pretreatment technologies for an efficient bioethanol production process based on enzymatic hydrolysis: A review. Bioresour. Technol. 2010, 101, 4851-4861. [CrossRef]

119. Isikgor, F.H.; Becer, C.R. Lignocellulosic biomass: A sustainable platform for the production of bio-based chemicals and polymers. Polym. Chem. 2015, 6, 4497-4559. [CrossRef]

120. Kumar, G.; Bakonyi, P.; Periyasamy, S.; Kim, S.H.; Nemestóthy, N.; Bélafi-Bakó, K. Lignocellulose biohydrogen: Practical challenges and recent progress. Renew. Sustain. Energy Rev. 2015, 44, 728-737. [CrossRef]

121. Sawatdeenarunat, C.; Surendra, K.C.; Takara, D.; Oechsner, H.; Khanal, S.K. Anaerobic digestion of lignocellulosic biomass: Challenges and opportunities. Bioresour. Technol. 2015, 178, 178-186. [CrossRef] [PubMed]

122. Fan, Y.; Klemes, J.J.; Lee, C.T. Pre- and post-treatment assessment for the anaerobic digestion of lignocellulosic waste: P-graph. Chem. Eng. Trans. 2018, 63, 1-6. [CrossRef]

123. Van Fan, Y.; Klemeš, J.J.; Perry, S.; Lee, C.T. Anaerobic digestion of lignocellulosic waste: Environmental impact and economic assessment. J. Environ. Manag. 2019, 231, 352-363. [CrossRef] [PubMed]

124. Soares, J.F.; Confortin, T.C.; Todero, I.; Mayer, F.D.; Mazutti, M.A. Dark fermentative biohydrogen production from lignocellulosic biomass: Technological challenges and future prospects. Renew. Sustain. Energy Rev. 2020, 117. [CrossRef]

125. Wyman, V.; Henríquez, J.; Palma, C.; Carvajal, A. Lignocellulosic waste valorisation strategy through enzyme and biogas production. Bioresour. Technol. 2018, 247, 402-411. [CrossRef] [PubMed]

126. Chakraborty, D.; Shelvapulle, S.; Reddy, K.R.; Kulkarni, R.V.; Puttaiahgowda, Y.M.; Naveen, S.; Raghu, A.V. Integration of biological pre-treatment methods for increased resource replace resource with energy recovery from paper and pulp biosludge. $J$. Microbiol. Methods 2019, 160, 93-100. [CrossRef]

127. Vasco-Correa, J.; Khanal, S.; Manandhar, A.; Shah, A. Anaerobic digestion for bioenergy production: Global status, environmental and techno-economic implications, and government policies. Bioresour. Technol. 2018, 247, 1015-1026. [CrossRef]

128. Olsson, L.; Hahn-Hägerdal, B. Fermentation of lignocellulosic hydrolysates for ethanol production. Enzym. Microb. Technol. 1996, 18, 312-331. [CrossRef]

129. De Vrije, T.; De Haas, G.; Tan, G.B.; Keijsers, E.R.P.; Claassen, P.A.M. Pretreatment of Miscanthus for hydrogen production by Thermotoga elfii. Int. J. Hydrogen Energy 2002, 27, 1381-1390. [CrossRef]

130. De Vrije, T.; Bakker, R.R.; Budde, M.A.W.; Lai, M.H.; Mars, A.E.; Claassen, P.A.M. Efficient hydrogen production from the lignocellulosic energy crop Miscanthus by the extreme thermophilic bacteria Caldicellulosiruptor saccharolyticus and Thermotoga neapolitana. Biotechnol. Biofuels 2009, 2. [CrossRef]

131. Akyol, Ç.; Ince, O.; Bozan, M.; Ozbayram, E.G.; Ince, B. Biological pretreatment with Trametes versicolor to enhance methane production from lignocellulosic biomass: A metagenomic approach. Ind. Crop. Prod. 2019, 140. [CrossRef]

132. Amend, J.P.; Shock, E.L. Energetics of overall metabolic reactions of thermophilic and hyperthermophilic Archaea and Bacteria. Fems Microbiol. Rev. 2001, 25, 175-243. [CrossRef]

133. Arnoult, S.; Brancourt-Hulmel, M. A Review on Miscanthus Biomass Production and Composition for Bioenergy Use: Genotypic and Environmental Variability and Implications for Breeding. BioEnergy Res. 2014, 8, 502-526. [CrossRef]

134. Abreu, A.A.; Tavares, F.; Alves, M.M.; Cavaleiro, A.J.; Pereira, M.A. Garden and food waste co-fermentation for biohydrogen and biomethane production in a two-step hyperthermophilic-mesophilic process. Bioresour. Technol. 2019, 278, 180-186. [CrossRef]

135. Moretti, P.; Morais de Araujo, J.; Borges de Castilhos, A.; Buffière, P.; Gourdon, R.; Bayard, R. Characterization of municipal biowaste categories for their capacity to be converted into a feedstock aqueous slurry to produce methane by anaerobic digestion. Sci. Total Environ. 2020, 716, 137084. [CrossRef] [PubMed]

136. Boldrin, A.; Christensen, T.H. Seasonal generation and composition of garden waste in Aarhus (Denmark). Waste Manag. 2010, 30, 551-557. [CrossRef]

137. Kadar, Z.; Vrije, T.; Budde, M.A.W.; Szengyel, Z.; Réczey, K.; Claassen, P.A. Hydrogen Production from Paper Sludge Hydrolysate. Appl. Biochem. Biotechnol. 2003, 105-108, 557-566. [CrossRef]

138. Logeswaran, V.; Ramakrishna, G. Waste Paper Sludge Ash-State of art. Int. J. Innov. Technol. Explor. Eng. 2019, 8, $2333-2338$. [CrossRef] 
139. Lin, Y.; Wu, S.; Wang, D. Hydrogen-methane production from pulp \& paper sludge and food waste by mesophilic-thermophilic anaerobic co-digestion. Int. J. Hydrogen Energy 2013, 38, 15055-15062. [CrossRef]

140. Nguyen, T.A.D.; Kim, K.R.; Nguyen, M.T.; Kim, M.S.; Kim, D.; Sim, S.J. Enhancement of fermentative hydrogen production from green algal biomass of Thermotoga neapolitana by various pretreatment methods. Int. J. Hydrogen Energy 2010, 35, 13035-13040. [CrossRef]

141. Dipasquale, L.; D’Ippolito, G.; Gallo, C.; Vella, F.M.; Gambacorta, A.; Picariello, G.; Fontana, A. Hydrogen production by the thermophilic eubacterium Thermotoga neapolitana from storage polysaccharides of the CO 2-fixing diatom Thalassiosira weissflogii. Int. J. Hydrogen Energy 2012, 37, 12250-12257. [CrossRef]

142. Santibáñez, C.; Varnero, M.T.; Bustamante, M. Residual glycerol from biodiesel Manufacturing, waste or potential source of Bioenergy: A review. Chil. J. Agric. Res. 2011, 71, 469-475. [CrossRef]

143. Safaei, H.R.; Shekouhy, M.; Rahmanpur, S.; Shirinfeshan, A. Glycerol as a biodegradable and reusable promoting medium for the catalyst-free one-pot three component synthesis of 4H-pyrans. Green Chem. 2012, 14, 1696-1704. [CrossRef]

144. Yang, F.; Hanna, M.A.; Sun, R. Value-added uses for crude glycerol-A byproduct of biodiesel production. Biotechnol. Biofuels 2012, 5, 13. [CrossRef]

145. Pachauri, N.; He, B. Value-added Utilization of Crude Glycerol from Biodiesel Production: A Survey of Current Research Activities. In Proceedings of the 2006 ASABE Annual International Meeting, Portland, OR, USA, 9-12 July 2006; Volume 0300.

146. Thompson, J.C.; He, B.B. Characterization of Crude Glycerol From Biodiesel Production from Multiple Feedstocks. Appl. Eng. Agric. 2006, 22, 261-265. [CrossRef]

147. Da Silva, G.P.; Mack, M.; Contiero, J. Glycerol: A promising and abundant carbon source for industrial microbiology. Biotechnol. Adv. 2009, 27, 30-39. [CrossRef] [PubMed]

148. Pyle, D.J. Use of Biodiesel-Derived Crude Glycerol for the Production of Omega-3 Polyunsaturated Fatty Acids by the Microalga Schizochytrium Limacinum. Ph.D. Thesis, Virginia Polytechnic Institute and State University, Balcksburg, VA, USA, 2008.

149. Hansen, C.F.; Hernandez, A.; Mullan, B.P.; Moore, K.; Trezona-Murray, M.; King, R.H.; Pluske, J.R. A chemical analysis of samples of crude glycerol from the production of biodiesel in Australia, and the effects of feeding crude glycerol to growing-finishing pigs on performance, plasma metabolites and meat quality at slaughter. Anim. Prod. Sci. 2009, 49, 154-161. [CrossRef]

150. Siles López, J.Á.; de los Martín Santos, M.Á.; Chica Pérez, A.F.; Martín Martín, A. Anaerobic digestion of glycerol derived from biodiesel manufacturing. Bioresour. Technol. 2009, 100, 5609-5615. [CrossRef]

151. Ngo, T.A.; Kim, M.S.; Sim, S.J. High-yield biohydrogen production from biodiesel manufacturing waste by Thermotoga neapolitana. Int. J. Hydrogen Energy 2011, 36, 5836-5842. [CrossRef]

152. Dasari, M. Crude Glycerol Potential Described. Feedstuffs, 15 October 2007; 1-3.

153. Maru, B.T.; Bielen, A.A.M.; Kengen, S.W.M.; Constantí, M.; Medina, F. Biohydrogen Production from Glycerol using Thermotoga spp. Energy Procedia 2012, 29, 300-307. [CrossRef]

154. Maru, B.T.; Bielen, A.A.M.; Constantí, M.; Medina, F.; Kengen, S.W.M. Glycerol fermentation to hydrogen by Thermotoga maritima: Proposed pathway and bioenergetic considerations. Int. J. Hydrogen Energy 2013, 38, 5563-5572. [CrossRef]

155. Nelson, K.E.; Clayton, R.A.; Gill, S.R.; Gwinn, M.L.; Dodson, R.J.; Haft, D.H.; Hickey, E.K.; Peterson, J.D.; Nelson, W.C.; Ketchum, K.A.; et al. Evidence for lateral gene transfer between archaea and bacteria from genome sequence of Thermotoga maritima. Nature 1999, 399, 323-329. [CrossRef]

156. Van Ooteghem, S.A.; Jones, A.; Van Der Lelie, D.; Dong, B.; Mahajan, D. H2 production and carbon utilization by Thermotoga neapolitana under anaerobic and microaerobic growth conditions. Biotechnol. Lett. 2004, 26, 1223-1232. [CrossRef] [PubMed]

157. Schröder, C.; Selig, M.; Schönheit, P. Glucose fermentation to acetate, CO2 and H2 in the anaerobic hyperthermophilic eubacterium Thermotoga maritima: Involvement of the Embden-Meyerhof pathway. Arch. Microbiol. 1994, 161, 460-470. [CrossRef]

158. Schut, G.J.; Adams, M.W.W. The iron-hydrogenase of Thermotoga maritima utilizes ferredoxin and NADH synergistically: A new perspective on anaerobic hydrogen production. J. Bacteriol. 2009, 191, 4451-4457. [CrossRef] [PubMed]

159. Khan, M.I.; Shin, J.H.; Kim, J.D. The promising future of microalgae: Current status, challenges, and optimization of a sustainable and renewable industry for biofuels, feed, and other products. Microb. Cell Fact. 2018, 17, 36. [CrossRef] [PubMed]

160. Miao, X.; Wu, Q. Biodiesel production from heterotrophic microalgal oil. Bioresour. Technol. 2006, 97, 841-846. [CrossRef]

161. Ramachandra, T.V.; Mahapatra, D.M.; Karthick, B.; Gordon, R. Milking diatoms for sustainable energy: Biochemical engineering versus gasoline-secreting diatom solar panels. Ind. Eng. Chem. Res. 2009, 48, 8769-8788. [CrossRef]

162. Latif, H.; Lerman, J.A.; Portnoy, V.A.; Tarasova, Y.; Nagarajan, H.; Schrimpe-Rutledge, A.C.; Smith, R.D.; Adkins, J.N.; Lee, D.-H.; Qiu, Y.; et al. The Genome Organization of Thermotoga maritima Reflects Its Lifestyle. Plos Genet. 2013, 9, e1003485. [CrossRef]

163. Rodionov, D.A.; Rodionova, I.A.; Li, X.; Ravcheev, D.A.; Tarasova, Y.; Portnoy, V.A.; Zengler, K.; Osterman, A.L. Transcriptional regulation of the carbohydrate utilization network in Thermotoga maritima. Front. Microbiol. 2013, 4, 244. [CrossRef] [PubMed]

164. Göker, M.; Spring, S.; Scheuner, C.; Anderson, I.; Zeytun, A.; Nolan, M.; Lucas, S.; Tice, H.; Del Rio, T.G.; Cheng, J.F.; et al Genome sequence of the Thermotoga thermarum type strain (LA3T) from an African solfataric spring. Stand. Genom. Sci. 2015, 9, 1105-1117. [CrossRef] [PubMed]

165. Ravcheev, D.A.; Khoroshkin, M.S.; Laikova, O.N.; Tsoy, O.V.; Sernova, N.V.; Petrova, S.A.; Rakhmaninova, A.B.; Novichkov, P.S.; Gelfand, M.S.; Rodionov, D.A. Comparative genomics and evolution of regulons of the LacI-family transcription factors. Front. Microbiol. 2014, 5, 294. [CrossRef] [PubMed] 
166. Xu, Z.; Puranik, R.; Hu, J.; Xu, H.; Han, D. Complete genome sequence of Thermotoga sp. strain RQ7. Stand. Genom. Sci. 2017, 12, 62. [CrossRef]

167. Beaucamp, N.; Hofmann, A.; Kellerer, B.; Jaenicke, R. Dissection of the gene of the bifunctional PGK-TIM fusion protein from the hyperthermophilic bacterium Thermotoga maritima: Design and characterization of the separate triosephosphate isomerase. Protein Sci. 1997, 6, 2159-2165. [CrossRef]

168. Shi, H.; Huang, Y.; Zhang, Y.; Li, W.; Li, X.; Wang, F. High-level expression of a novel thermostable and mannose-tolerant $\beta$-mannosidase from Thermotoga thermarum DSM 5069 in Escherichia coli. Bmc Biotechnol. 2013, 13. [CrossRef]

169. Martín Del Campo, J.S.; Chun, Y.; Kim, J.E.; Patiño, R.; Zhang, Y.H.P. Discovery and characterization of a novel ATP/polyphosphate xylulokinase from a hyperthermophilic bacterium Thermotoga maritima. J. Ind. Microbiol. Biotechnol. 2013, 40, 661-669. [CrossRef]

170. Fatima, B.; Aftab, M.N.; Haq, I.U. Cloning, purification, and characterization of xylose isomerase from Thermotoga naphthophila RKU-10. J. Basic Microbiol. 2016, 56, 949-962. [CrossRef]

171. Latif, H.; Sahin, M.; Tarasova, J.; Tarasova, Y.; Portnoy, V.A.; Nogales, J.; Zengler, K. Adaptive evolution of Thermotoga maritima reveals plasticity of the ABC transporter network. Appl. Environ. Microbiol. 2015, 81, 5477-5485. [CrossRef]

172. Xu, W.; Zhang, W.; Zhang, T.; Jiang, B.; Mu, W. l-Rhamnose isomerase and its use for biotechnological production of rare sugars. Appl. Microbiol. Biotechnol. 2016, 100, 2985-2992. [CrossRef] [PubMed]

173. Bertoldo, C.; Antranikian, G. Starch-hydrolyzing enzymes from thermophilic archaea and bacteria. Curr. Opin. Chem. Biol. 2002, 6, 151-160. [CrossRef]

174. Botha, J.; Mizrachi, E.; Myburg, A.A.; Cowan, D.A. Carbohydrate active enzyme domains from extreme thermophiles: Components of a modular toolbox for lignocellulose degradation. Extremophiles 2018, 22, 1-12. [CrossRef] [PubMed]

175. Jung, S.; Lee, D.S.; Kim, Y.O.; Joshi, C.P.; Bae, H.J. Improved recombinant cellulase expression in chloroplast of tobacco through promoter engineering and $5^{\prime}$ amplification promoting sequence. Plant. Mol. Biol. 2013, 83, 317-328. [CrossRef] [PubMed] 